\title{
Vitamin K Dependent Proteins in Kidney Disease
}

\author{
Ciprian N. Silaghi ${ }^{1, *}$, Tamás Ilyés ${ }^{1}$, Vladimir P. Filip ${ }^{1}$, Marius Farcaș ${ }^{1}$, \\ Adriana J. van Ballegooijen ${ }^{2}$ and Alexandra M. Crăciun ${ }^{1}$ (D) \\ 1 Department of Molecular Sciences, University of Medicine and Pharmacy "Iuliu Hatieganu”, 400012 \\ Cluj-Napoca, Romania; tamasilyes94@gmail.com (T.I.); vladimirpfilip@gmail.com (V.P.F.); \\ farcasmarius47@gmail.com (M.F.); acraciun@umfcluj.ro (A.M.C.) \\ 2 Department of Nephrology \& Epidemiology and Biostatistics, Amsterdam University Medical Center, \\ VUmc, 1117 HV Amsterdam, The Netherlands; aj.vanballegooijen@vumc.nl \\ * Correspondence: silaghi.ciprian@umfcluj.ro
}

Received: 20 February 2019; Accepted: 27 March 2019; Published: 29 March 2019

\begin{abstract}
Patients with chronic kidney disease (CKD) have an increased risk of developing vascular calcifications, as well as bone dynamics impairment, leading to a poor quality of life and increased mortality. Certain vitamin K dependent proteins (VKDPs) act mainly as calcification inhibitors, but their involvement in the onset and progression of CKD are not completely elucidated. This review is an update of the current state of knowledge about the relationship between CKD and four extrahepatic VKDPs: matrix Gla protein, osteocalcin, growth-arrest specific protein 6 and Gla-rich protein. Based on published literature in the last ten years, the purpose of this review is to address fundamental aspects about the link between CKD and circulating VKDPs levels as well as to raise new topics about how the interplay between molecular weight and charge could influence the modifications of circulating VKDPs at the glomerular level, or whether distinct renal etiologies have effect on VKDPs. This review is the output of a systematic literature search and may open future research avenues in this niche domain.
\end{abstract}

Keywords: Vitamin K dependent proteins; matrix Gla protein; osteocalcin; Gas6; Gla-rich protein; chronic kidney disease; calcification

\section{Introduction}

Chronic kidney disease (CKD) has a major influence on the quality of life in many patients. Therefore, it is important to develop early intervention methods for better management of complications and to decrease CKD mortality. While there are various markers used to assess the stages of CKD, the effectiveness of treatment is low since none of these newly discovered molecules and mechanisms improve disease progression [1,2].

Vitamin $\mathrm{K}$ comprises a group of fat-soluble vitamins that act as co-factor for $\gamma$-glutamyl carboxylase, which activates several vitamin K-dependent proteins (VKDPs). VKDPs play a major role in hemostasis and bone health, but also in the progression of vascular calcification (VC), which is strongly associated with cardiovascular risk [3] and CKD mortality [4,5]. Several VKDPs also have important roles as ligands in apoptotic pathways with a significant implication in cancer therapy and disease progression [6-8]. The four most acknowledged extrahepatic VKDPs we selected for this review are: matrix Gla protein (MGP), osteocalcin (OC), growth arrest specific protein 6 (Gas6) and Gla-rich protein (GRP).

The activity of VKDPs is influenced by their carboxylation status, thus being dependent on vitamin $\mathrm{K}$ level. Vitamin K deficiency, assessed by the uncarboxylated conformations of MGP and OC was found to be common in patients with CKD [9] and hemodialysis (HD) [10]. To date, there is 
no gold standard to measure vitamin K sufficiency, therefore an assessment of different circulating VKDPs and monitoring dietary intake are applied.

To our knowledge, no reviews were published in the past ten years on the significance of MGP, OC, Gas6 and GRP in CKD. Taking into consideration the growing state of knowledge and the fast pace of research in this field, we aim to offer a comprehensive analysis of studies from the past ten years (cross-sectional, prospective cohort, meta-analyses and interventional studies) with attention being directed towards understanding the molecular mechanisms of VKDPs in CKD. We analyzed the implication of the four VKDPs in CKD, hemodialysis (HD), peritoneal dialysis, renal transplant, acute renal injury, nephrolithiasis, renal cancer or related in-vitro studies. We also approached new topics on the interaction between molecular weight and charge of VKDPs at glomerular level, about the influence of CKD etiologies upon VKDPs and the relationship between circulating VKDPs levels and the progression of CKD.

\section{Methodology}

\subsection{Search Strategy and Selection of Studies}

All databases accessible through the PubMed search engine were selected for this review. Human, as well as animal and in vitro studies were taken into consideration, but only articles published in the past ten years were selected for screening. The set of search terms was jointly agreed upon by the authors, and subsequently used during the initial selection process. The search terms are summarized in Table 1.

Table 1. Summary of searching strategy.

\begin{tabular}{|c|c|c|c|c|c|}
\hline \multirow{2}{*}{ Protein } & \multirow{2}{*}{ Search Term } & \multirow{2}{*}{ Date } & \multicolumn{2}{|c|}{ Number of Results } & \multirow{2}{*}{$\begin{array}{c}\text { Number of } \\
\text { Studies Included }\end{array}$} \\
\hline & & & By Search Term & Total & \\
\hline \multirow[t]{2}{*}{ MGP } & $\begin{array}{l}\text { "Matrix Gla protein AND kidney } \\
\text { disease" }\end{array}$ & 15 August 2018 & 132 & \multirow[t]{2}{*}{224} & \multirow[t]{2}{*}{31} \\
\hline & “MGP AND kidney disease" & 2 September 2018 & 92 & & \\
\hline \multirow{2}{*}{$\mathrm{OC}$} & “Osteocalcin AND kidney disease" & 19 September 2018 & 235 & \multirow{2}{*}{470} & \multirow{2}{*}{29} \\
\hline & "Osteocalcine AND kidney disease" & 19 September 2018 & 235 & & \\
\hline \multirow{2}{*}{ Gas6 } & "Gas6 AND kidney disease" & 2 September 2018 & 34 & \multirow{2}{*}{63} & \multirow{2}{*}{16} \\
\hline & $\begin{array}{c}\text { "Growth arrest specific protein } 6 \text { AND } \\
\text { kidney disease" }\end{array}$ & 2 September 2018 & 29 & & \\
\hline \multirow{3}{*}{ GRP } & "GRP AND kidney disease" & 2 September 2018 & 38 & \multirow{3}{*}{45} & \multirow{3}{*}{1} \\
\hline & "Gla rich protein AND kidney disease" & 2 September 2018 & 5 & & \\
\hline & "Gla-rich protein AND kidney disease" & 2 September 2018 & 2 & & \\
\hline
\end{tabular}

Note: Search terms used for each protein, dates at which the databases were accessed and the results retrieved, number of results retrieved, number of studies included in review according to inclusion and exclusion criteria. Abbreviations: MGP, matrix Gla protein; OC, osteocalcin; Gas6, growth arrest specific protein 6; GRP, Gla-rich protein.

Each search term was introduced into the search engine, then a list was made for each set of results and the date when the databases were accessed was noted. The lists for each protein were cross-checked for duplicates between search terms and then duplicates were subsequently removed. From these lists, only articles written in English and only those that had abstracts were reviewed. After reviewing the abstracts, full text articles were obtained for each eligible article, which were assessed according to the inclusion and exclusion criteria.

\subsection{Inclusion and Exclusion Criteria}

The inclusion and exclusion criteria were jointly agreed upon by the authors. The inclusion criteria were as follows: written in the past 10 years, written and published in English, concerning CKD, hemodialysis, peritoneal dialysis, renal transplant, renal cancer, acute renal injury, nephrolithiasis or related in-vitro cellular studies. Exclusion criteria were: reviews, systematic reviews, genetic analysis studies, studies concerning the effects of vitamin $\mathrm{K}$ antagonists, studies concerning 
hormonal effects and/or treatment, studies concerning vitamin D supplementation, studies concerning immunosuppressive treatment, inability to determine the exact type of protein studied and studies that were lacking clear method definition.

Most studies were related to CKD, defined as the reduction of kidney filtration, estimated by the glomerular filtration rate (eGFR). Decreasing eGFR denoted a directly proportional decrease in kidney filtration capacity, being the main criteria by which CKD was classified into stages. Stage V of CKD was also referred to as end-stage renal disease (ESRD) [11].

\subsection{Identification, Selection, Screening and Inclusion}

The process of identification, selection, screening and inclusion of the studies are depicted in Figure 1. The following studies were included: MGP [12-42]; OC [9,10,43-69]; Gas6 [70-85]; and GRP [86].

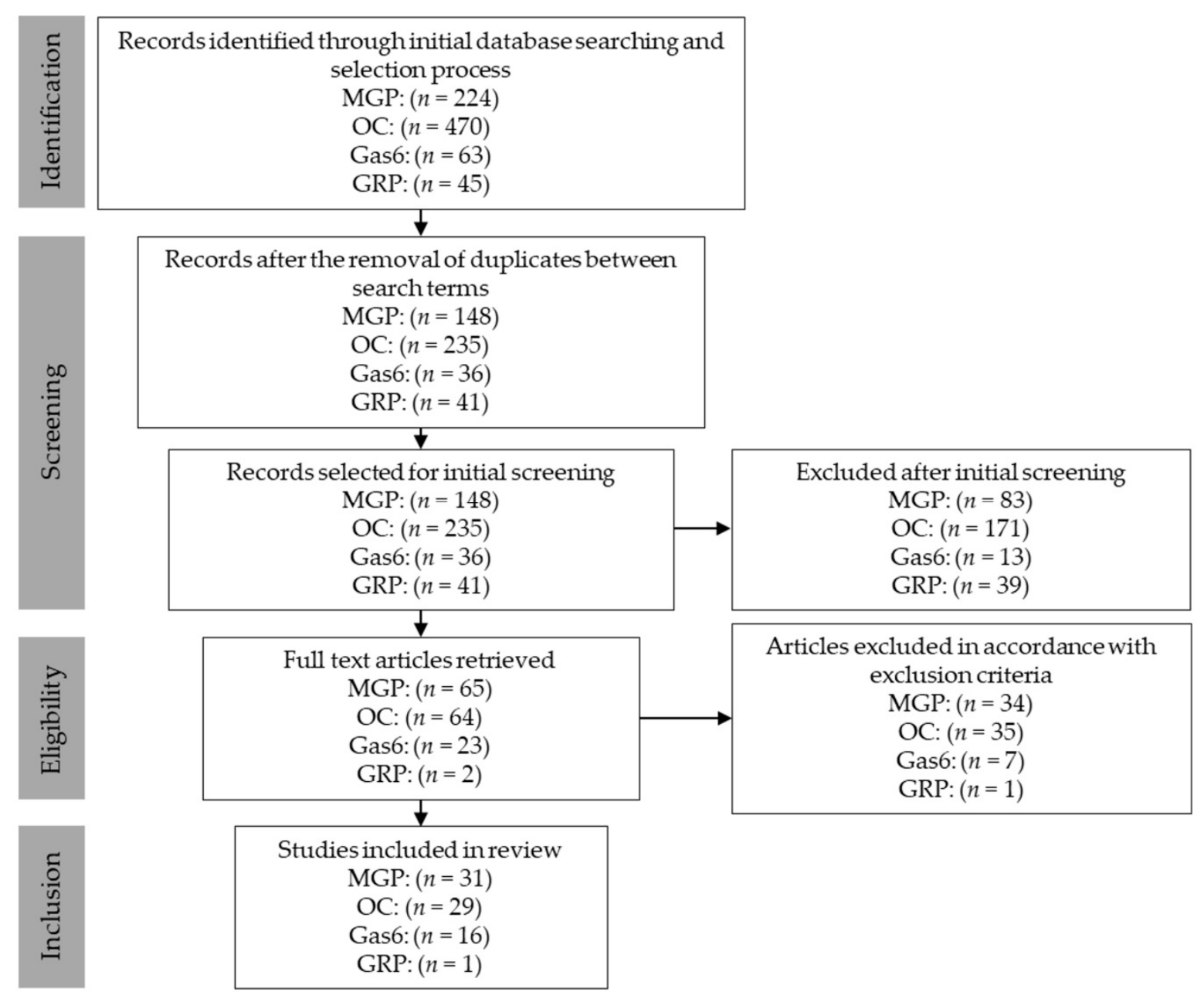

Figure 1. Flow diagram of the processes from identification, selection and screening to inclusion. Abbreviations: MGP, matrix Gla protein; OC, osteocalcin; Gas6, growth arrest specific protein 6; GRP, Gla-rich protein.

\section{Functional and Molecular Background}

\subsection{Matrix Gla Protein}

MGP is a $10.6 \mathrm{kDa}$ protein, comprised of 84 amino acids which contains nine glutamic acid (Glu) residues but also five serine (Ser) residues, being insoluble in water [87]. MGP is synthesized 
and secreted in the extracellular matrix mainly by vascular smooth muscle cells (VSMCs) and chondrocytes [88].

To exert its biological role as calcification inhibitor, MGP needs to be fully carboxylated and in phosphorylated conformation (p-cMGP). With the contribution of vitamin K as cofactor [89], the carboxylation of the five Glu residues in positions $2,37,41,48$ and 52 is facilitated by $\gamma$-glutamyl carboxylase, becoming $\gamma$-carboxy glutamic acid (Gla) residues. In addition, three Ser residues are phosphorylated in positions 3, 6 and 9 with the help of the casein kinase [90,91]. These post-translational extrahepatic modifications ensure the normal function of MGP as VC inhibitor.

There is strong evidence suggesting that carboxylated MGP (cMGP) inhibits VC by binding $\mathrm{Ca}^{2+}$ ions via the $-\mathrm{COOH}$ groups from the Gla residues [87]. cMGP also binds to hydroxyapatite molecules, while uncarboxylated MGP (ucMGP) was associated with progression of VC [92,93]. Moreover, dephospho-uncarboxylated MGP (dp-ucMGP), the inactive conformation, was associated with increased VC in patients with ESRD [12]. There are also available assays that cannot discriminate between different conformations of MGP, designated as total MGP (t-MGP); however, these assays have not yet been studied in CKD [94].

In rats, the calcium clearance was accomplished by a high molecular weight circulating complex consisting of MGP, fetuin-A, hydroxyapatite and other proteins [95] The same study postulated that serum proteins of 10-kDa (such as MGP) are cleared rapidly by kidney filtration (serum half-life $=5$ $\mathrm{min}$ ), the increase of MGP serum level being caused by new synthesis of MGP and that $\gamma$-carboxylation is necessary for its binding to this circulating complex. As regards to MGP, this mineral complex has not yet been confirmed in humans, MGP exerting its activity as VC inhibitor in tissues, not in circulation.

The molecular mechanisms of MGP and the main physiological function as inhibitor of VC are summarized in Figure 2 [12,87,89-93,96].



Figure 2. Molecular mechanisms and physiological function of MGP. Abbreviations: MGP, matrix gla protein; Glu, glutamic acid; Gla, $\gamma$-carboxy-glutamic acid; Ser, serine; dp-ucMGP, dephospho-uncarboxylated MGP; p-ucMGP, phosphorylated-uncarboxylated MGP; p-uMGP, phosphorylated-carboxylated MGP; VSMCs, vascular smooth muscle cells.

\subsection{Osteocalcin}

While MGP is produced mainly by VSMCs, OC is secreted exclusively in bone by osteoblasts, only a small part of it diffuses into the systemic circulation [97]. Having a molecular weight of $5.6 \mathrm{kDa}$ and containing around 49 amino acids [97], this water soluble protein is the smallest molecule among the four VKDPs. OC undergoes similar post translational vitamin $\mathrm{K}$ dependent $\gamma$-carboxylation as MGP [98]. Depending on carboxylation status, OC presents two possible conformations: uncarboxylated OC (ucOC) and carboxylated OC ( $\mathrm{COC}$ ) with three Gla residues. Different variables (e.g., age and menopausal status) may influence the circulating $\mathrm{OC}$ fractions. In this respect, both circulating ucOC and $\mathrm{COC}$ were higher in older women, but only ucOC was correlated with advancing age [99]. 
Besides bone dynamics, where OC is a validated marker of bone turnover, it is also a hormone that regulates glucose metabolism $[100,101]$. It was demonstrated that ucOC, the active endocrine conformation, stimulates insulin secretion either directly in the pancreas or indirectly by means of increasing glucagon-like peptide- 1 secretion in the small intestine, as well as release of adiponectin in adipose tissue, therefore enhancing insulin sensitivity in muscle [100]. Moreover, insulin signaling in osteoblasts was found to be a positive modulator for OC expression but also for its activation through the capability to enhance bone resorption indirectly by osteoclasts [101].

When bone is resorbed, OC fragments are released into the circulation, thus plasma concentrations may reflect bone turnover. The clearance of $\mathrm{OC}$ in humans is through glomerular filtration (plasma half-life $=20 \mathrm{~min}$ ), the levels of serum intact OC being higher in patients with CKD compared with age-matched controls [102].

For the relationship between OC and VC, a consistent association was reported [98]. Circulating ucOC is proposed as marker of subclinical atherosclerosis in non-dialysis patients with CKD, because lower circulating levels of ucOC could discriminate between patients and a healthy population [103].VSMCs from calcified atheroma plaques have also been found to significantly express OC, especially in HD patients [98,104].

The systemic and bone specific effects of OC are summarized in Figure 3 [97,100,105-108].

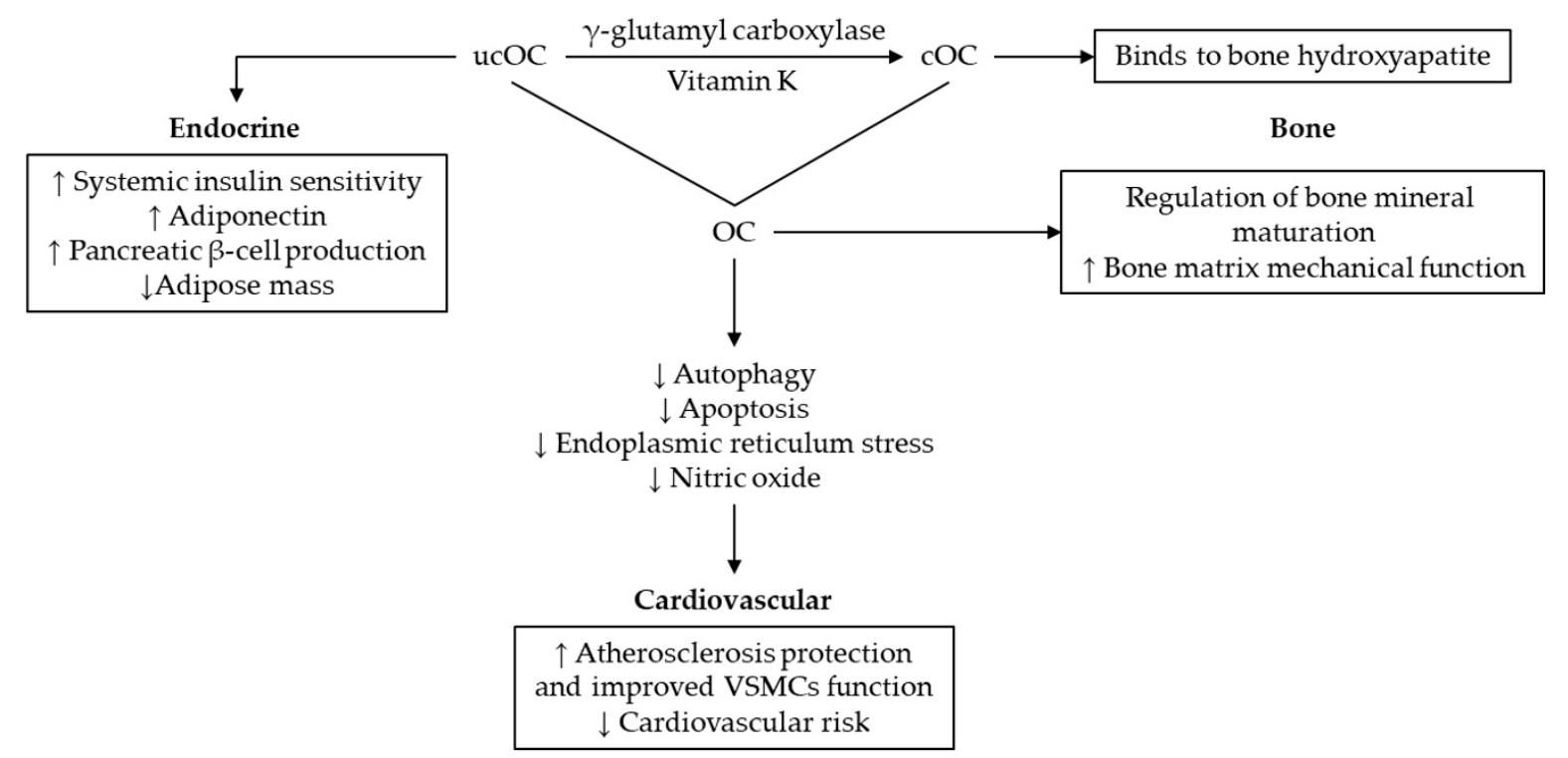

Figure 3. Systemic and bone specific effects of OC. Abbreviations: OC, osteocalcin; ucOC, uncarboxylated OC; COC, carboxylated OC; VSMCs, vascular smooth muscle cells.

\subsection{Growth Arrest Specific Protein 6}

Gas6, a protein with a N-terminal Gla domain, has a molecular weight of $75 \mathrm{kDa}$, but an idiosyncratic function among VKDPs, being involved in multiple physiological activities ranging from cellular homeostasis, cell proliferation to cell survival [109-111]. Similar to other VKDPs, the carboxylation is carried out with the help of vitamin $\mathrm{K}$ dependent $\gamma$-glutamyl carboxylase. Because of its carboxylated Gla domain, the $\mathrm{Ca}^{2+}$ binding activity increases, leading to multiple protein-protein interactions. Cells that express the Gas6 gene vary from leukocytes and endothelial cells to VSMCs, with the assumption that Gas6 would act as a growth factor-like molecule in the proliferation of VSMCs [112].

Structurally and functionally related to Protein S, Gas6 has been shown to be a ligand for the TAM receptor family (Tyro3-Axl-Mer) [6,113]. These tyrosine-kinase receptors are key controllers of cell survival and proliferation processes. Dysregulation in any of its molecular components leads to evasion of cancer immune system and drug resistance mechanisms [8]. Studies that investigated the Gas6/TAM 
pathway in cancer therapy highlighted its importance, but the exact mechanism is still elusive [114]. Gas6 and soluble Axl are present in human circulation at nanomolar level concentrations [115].

The general mechanism of action for Gas6 is summarized in Figure $4[6,8,113,114]$.

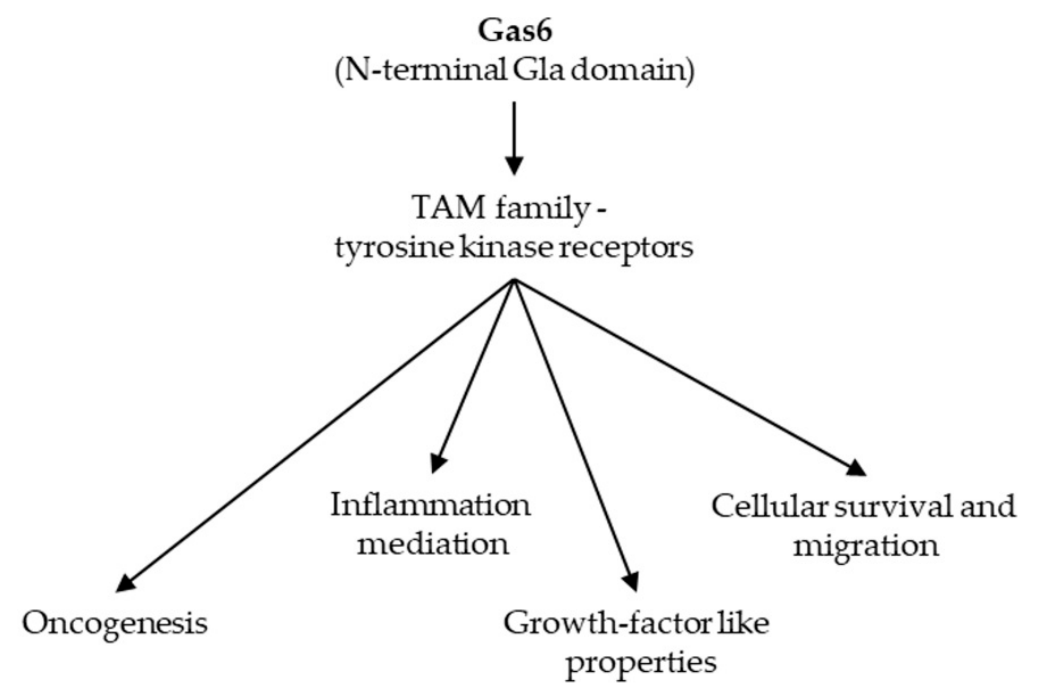

Figure 4. General mechanism of action for Gas6. Abbreviations: Gas6, growth arrest specific protein 6; TAM, Tyro3-Axl-Mer.

\subsection{Gla-Rich Protein}

The etymology of GRP, the most recently discovered member of the VKDPs family, originates from its large number of Gla residues [116]. GRP has a molecular weight of $10.2 \mathrm{kDa}$ and contains 74 amino acids of which sixteen are Gla residues, yet being insoluble at neutral $\mathrm{pH}$ [117]. GRP is involved in the inhibition of articular and cardiovascular calcifications $[118,119]$. It is mainly found in skin, bone vasculature and cartilage, where it functions as a calcification inhibitor $[119,120]$.

Since GRP was associated with the presence of calcification, it might prevent calcium-induced signaling pathways, leading to inhibition of calcium crystal formation $[117,121,122]$. The mechanisms for calcium binding are similar to MGP; its high number of - $\mathrm{COOH}$ containing Gla residues enhance GRP's ability to bind large amounts of calcium ions, even more than other VKDPs. Moreover, GRP has been shown to have the same capability of binding to hydroxyapatite crystals as MGP [122].

\section{VKDPs in Kidney Disease}

\subsection{Vitamin K Insufficiency in Kidney Disease}

Vitamin K insufficiency has been found to be present in the majority of CKD and HD patients [9,10], however the origin for the poor vitamin $\mathrm{K}$ status in these populations has not yet been fully elucidated. The only conceivable reason found was an apparent lower vitamin $\mathrm{K}$ intake related to the dietary routine recommended in $\mathrm{CKD}$ and $\mathrm{HD}$, which limits sodium and potassium and consequently reduces the intake of foods with high vitamin $\mathrm{K}$ content [10].

The higher levels of plasma dp-ucMGP found in patients with CKD and HD validates the theory of a poor vascular vitamin $\mathrm{K}$ status, which is an underlying cause for VC and cardiovascular related mortality in these patients [10,13-15,42]. Furthermore, considering the assessment of the total OC percentage that is not carboxylated (\%ucOC), a subclinical vitamin $\mathrm{K}$ deficiency was found in $60 \%$ of patients with CKD stages III-V [9].

Figure 5 summarizes the modifications of different MGP and OC conformations in CKD and the effects of vitamin $\mathrm{K}$ insufficiency upon these proteins [9,10,12-26,42-44]. 


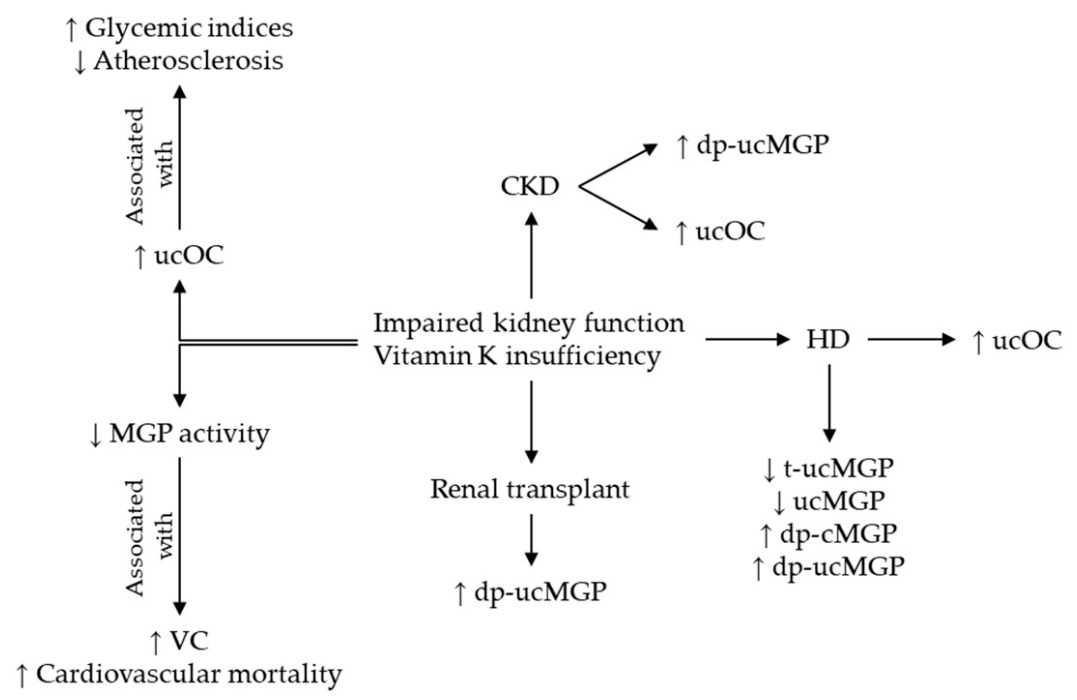

Figure 5. Modification of circulating MGP and OC in CKD. Abbreviations: CKD, chronic kidney disease; OC, osteocalcin, ucOC, uncarboxylated OC; $\mathrm{cOC}=$ carboxylated OC; MGP, matrix Gla protein; dp-ucMGP, dephospho-uncarboxylated MGP; t-ucMGP, total-uncarboxylated MGP; ucMGP, uncarboxylated MGP; dp-cMGP, dephospho-carboxylated MGP.

\subsection{Matrix Gla Protein in Kidney Disease}

\subsubsection{Human Studies on Circulating MGP}

Studies analyzing the variation of circulating MGP levels in patients with kidney disease are summarized in Table 2. A glance at the studies using dual-antibody assays (dp-ucMGP or dp-cMGP) shows that all of the circulating MGP conformations were higher in patients with different CKD stages, HD or renal transplant compared to a healthy population. In these studies, the levels of dp-ucMGP are higher with CKD stages and were associated with different localizations of VC. However, no association was found between plasma dp-ucMGP levels and calcified carotid intima media thickness in patients with diabetic nephropathy (DN) [27]. On the contrary, the serum MGP conformations using mono-antibody assays, such as ucMGP and t-ucMGP (a modified assay after ucMGP), were found decreased in the same pathologies in adults [25] and children [26]. Cranenburg et al. [25] showed that serum ucMGP concentrations were inversely associated with the extent of VC in HD patients, but in non-diabetic HD patients ucMGP was not associated with VC [28].

Table 2. Human studies on circulating MGP.

\begin{tabular}{|c|c|c|c|c|}
\hline Reference & Study Type & $\begin{array}{c}\text { Number of Patients and } \\
\text { Disease State }\end{array}$ & $\begin{array}{c}\text { MGP } \\
\text { Conformations }\end{array}$ & $\begin{array}{l}\text { MGP Variation vs. } \\
\text { Controls }\end{array}$ \\
\hline Schlieper et al. 2011 [12] & cross-sectional & $188, \mathrm{HD}$ & $\begin{array}{l}\text { dp-ucMGP } \\
\text { dp-cMGP }\end{array}$ & Both higher \\
\hline Meuwese et al. 2015 [16] & cross-sectional & 97, HD & t-ucMGP & Lower \\
\hline Schurgers et al. 2010 [17] & prospective cohort & 107, CKD stages II-V and HD & dp-ucMGP & Higher \\
\hline Puzantian et al. 2018 [18] & prospective cohort & 137, CKD stages II-V & dp-ucMGP & Higher \\
\hline Fain et al. 2018 [19] & cross-sectional & $37, \mathrm{HD}$ & dp-ucMGP & Higher \\
\hline Westenfeld et al. 2012 [20] & interventional & 53, HD & dp-ucMGP & Higher \\
\hline Mansour et al. 2017 [21] & interventional & 60 , Renal transplant & dp-ucMGP & Higher \\
\hline Jansz et al. 2018 [22] & cross-sectional & $\begin{array}{c}\text { 82, HD; } 31 \text {, peritoneal dialysis; } \\
\text { 36, Renal transplant }\end{array}$ & dp-ucMGP & Lower than HD \\
\hline Boxma et al. 2012 [23] & prospective cohort & 60 , Renal transplant & dp-ucMGP & Higher \\
\hline Keyzer et al. 2015 [24] & prospective cohort & 518 , Renal transplant & dp-ucMGP & Higher \\
\hline Cranenburg et al. 2009 [25] & cross-sectional & 40, HD & ucMGP & Lower \\
\hline Shroff et al. 2008 [26] & cross-sectional & 61, HD & ucMGP & Lower \\
\hline
\end{tabular}

Abbreviations: MGP, matrix Gla protein; dp-ucMGP, dephospho-uncarboxylated MGP; dp-cMGP, dephospho-carboxylated MGP; t-ucMGP, total-uncarboxylated MGP; ucMGP, uncarboxylated MGP; HD, hemodialysis; CKD, chronic kidney disease; vs, versus. 
How can MGP modifications be explained in the context of these conflicting results? None of the studies mentioned above have assessed total MGP levels, thus low serum ucMGP may reflect either a reduced MGP production or a poor carboxylation status for ucMGP due to vitamin K insufficiency in CKD and HD patients. It is noteworthy that assays using ucMGP or t-ucMGP cannot detect the phosphorylated conformations of MGP or its fragments. A hypothesis was proposed by Cranenburg et al. [25] that ucMGP binds to the areas of calcification by its negatively phospho-Ser residues. To support this hypothesis, the levels of circulating phosphorylated MGP were lower in patients with highly calcified CKD [17]. Therefore, due to the lack of phospho-Ser residues, dp-ucMGP could be delivered more rapidly than ucMGP into the bloodstream.

In addition, different responses after vitamin $\mathrm{K}$ supplementation were reported for the MGP species in patients with CKD: plasma levels of dp-ucMGP decreased after vitamin $\mathrm{K}_{2}$ supplementation [15,38], while vitamin $\mathrm{K}_{1}$ intake was not associated with circulating ucMGP levels [39]. Kurnatowska et al. [38] noticed that administration of vitamin $K_{2}$ in patients with CKD stages III-V did not have an effect on the progression of VC. On the contrary, treatment with lanthanum carbonate (a non-calcium and non-aluminum based phosphate binder) in maintenance HD patients with diabetes and adynamic bone disease could delay the progress of coronary artery calcification, showing a significant decrease in serum MGP compared to baseline [40].

\subsubsection{MGP in Experimental Studies}

There are also in vitro studies assaying MGP levels in different supernatants from calcifying VSMCs incubated in serum of HD patients. The results are summarized in Table 3.

Table 3. In vitro studies concerning MGP.

\begin{tabular}{|c|c|c|}
\hline Reference & Type of Cells & Findings \\
\hline Willy et al. 2018 [29] & $\begin{array}{l}\text { Supernatants from calcifying VSMCs incubated } \\
\text { in serum of HD patients }\end{array}$ & Lower in HRO group than HF group \\
\hline Willy et al. 2017 [30] & $\begin{array}{c}\text { Supernatants from calcifying VSMCs incubated } \\
\text { in serum of HD patients }\end{array}$ & $\begin{array}{l}\text { Lower in } \mathrm{MCO} \text { group than HF group } \\
\text { Lower in } \mathrm{HCO} \text { group than HF group }\end{array}$ \\
\hline Khan et al. 2014 [31] & Induced nephrolithiasis on MDCK cells culture & Increased MGP expression \\
\hline Lu et al. 2013 [32] & Kidneys of hyperoxaluric rats & Increased MGP expression \\
\hline
\end{tabular}

Abbreviations: MGP, Matrix Gla protein; HRO, High Retention Onset dialysis; HF, conventional High Flow dialysis; HCO, High Cut-Off dialysis; MCO, Medium Cut-Off dialysis; MDCK, Madin-Darby Canine Kidney.

Willy et al. [30] found that serum samples from patients after High Cut-Off dialysis (HCO) have a reduced capacity to induce in vitro calcification in VSMCs compared to patients after conventional High Flow dialysis (HF). A possible explanation of this decline in pro-calcifying activity could be that, after incubation with serum from HF, VSMCs produced considerably higher anti-calcifying proteins (e.g., MGP) than VSMCs incubated in HCO or Medium Cut-Off dialysis (MCO) serums, as a compensatory response to the augmented calcification environment. In addition, according to Willy et al. [29], High Retention Onset dialyzers (HRO) may offer a treatment option to diminish the progression of $\mathrm{VC}$, but they come with significant albumin loss. As an alternative, the HRO with a steeper cut-off in their dialysis membrane are faintly less permeable, sustaining the desired effect on in vitro calcification, meanwhile limiting the albumin loss.

To sustain the anti-calcifying function of MGP, it was demonstrated that oxalate and hydroxyapatite crystals are able to provoke renal epithelial cells to produce MGP in an induced nephrolithiasis model on both young rats and tissue culture [31,32]. Khan et al. [31] stated that contact of renal epithelial cells to oxalate generates reactive oxygen species and consequently oxidative stress. Thus, the enhanced expression of MGP by exposure to reactive oxygen species leads to atherogenic stimuli. Several studies were conducted in adults and children [123] to find a better marker for oxidative stress and it would be an interesting direction for future studies to assess the relationship between MGP and oxidative stress in patients with kidney disease. 


\subsubsection{Studies Assessing MGP in Tissues}

In Table 4, the studies on the assessment of MGP in tissues are presented.

Table 4. Assessment of MGP in tissues.

\begin{tabular}{|c|c|c|c|}
\hline Reference & Pathology & MGP Conformations & Findings \\
\hline $\begin{array}{l}\text { Lomashvili et al. } \\
\quad 2011 \text { [33] }\end{array}$ & $\begin{array}{l}\text { Induced renal failure with VC } \\
\text { (rats) }\end{array}$ & cMGP, ucMGP & $\begin{array}{l}\text { Both had increased expression in } \\
\text { calcified aortic VSMCs }\end{array}$ \\
\hline $\begin{array}{l}\text { Lorenzen et al. } \\
\quad 2012[34]\end{array}$ & $\begin{array}{l}\text { Renal allograft calcification } \\
\text { (humans) }\end{array}$ & MGP & $\begin{array}{l}\text { Increased expression versus } \\
\text { non-calcified allografts }\end{array}$ \\
\hline $\begin{array}{l}\text { Kramann et al. } \\
\quad 2013 \text { [35] }\end{array}$ & $\begin{array}{l}\text { Calcific uremic arteriolopathy } \\
\text { (humans) }\end{array}$ & ucMGP & Increased expression in skin \\
\hline $\begin{array}{l}\text { Shroff et al. } 2008 \\
\text { [36] }\end{array}$ & HD (humans) & cMGP, ucMGP & $\begin{array}{c}\text { Increased expression in calcified } \\
\text { blood vessels }\end{array}$ \\
\hline Wei et al. 2016 [37] & $\begin{array}{l}\text { Renal tissue from CKD patients vs. } \\
\text { healthy donors (humans) }\end{array}$ & cMGP, ucMGP & $\begin{array}{l}\text { Both were present in calcified } \\
\text { renal tissue }\end{array}$ \\
\hline
\end{tabular}

Abbreviations: MGP, matrix Gla protein; VC, vascular calcification; ucMGP, uncarboxylated MGP; dp-ucMGP, dephospho-uncarboxylated MGP; HD, hemodialysis; vs, versus.

In all the studies on tissues in which the presence of calcifications was validated by von Kossa staining, ucMGP and cMGP were present nearby the calcification sites.

Shroff et al. [36] found increased amounts of ucMGP compared with cMGP in dialysis vessels, whereas control vessels had predominantly cMGP. The presence of MPG conformations was evocative for the vesicle-mediated calcification process. The study also demonstrated that hydroxyapatite crystals were released from dead VSMCs, thus confirming their role to initiate calcification.

Moreover, tissue from patients with CKD (e.g., interstitial nephritis) revealed calcium deposits with both ucMGP and cMGP conformations constantly co-localized with the micro-calcifications [37]. On the contrary, in normal renal tissue, the micro-calcifications were absent and the staining for both MGP conformations was negative. The study per se was first to demonstrate local vitamin K deficiency in renal tissue collected from CKD patients compared to healthy donors.

\subsection{Osteocalcin in Kidney Disease}

\subsubsection{Osteocalcin in CKD and Renal Transplant}

Studies addressing the variations of serum OC levels in human subjects with CKD and renal transplant are summarized in Table 5.

Table 5. Variations of serum OC levels in human studies.

\begin{tabular}{|c|c|c|c|c|}
\hline Reference & Type of Study & $\begin{array}{l}\text { Number of Patients } \\
\text { and Disease State }\end{array}$ & OC Conformation & Findings \\
\hline Holden et al. 2010 [9] & cross-sectional & $172, \mathrm{CKD}$ stages III-V & $\%$ ucOC & $\begin{array}{l}\text { Higher as CKD progresses, } \\
\text { associated with CKD stage }\end{array}$ \\
\hline $\begin{array}{l}\text { Gluba- Brzózka et al. } \\
2016 \text { [45] }\end{array}$ & cross-sectional & 80, CKD stages I-V & Intact OC & $\begin{array}{l}\text { Non-significant decreasing } \\
\text { trend as CKD advance }\end{array}$ \\
\hline $\begin{array}{l}\text { Kovesdy et al. } 2011 \\
{[46]}\end{array}$ & prospective cohort & $\begin{array}{l}\text { 639, Post renal } \\
\text { transplant with CKD } \\
\text { stages III-IV }\end{array}$ & Intact OC & $\begin{array}{l}\text { Higher in post renal } \\
\text { transplant patients with CKD } \\
\text { stage IV than CKD stage III }\end{array}$ \\
\hline
\end{tabular}

Abbreviations: OC, osteocalcin; \%ucOC, percentage of total OC that is uncarboxylated; $\mathrm{CKD}$, chronic kidney disease.

As a common complication in CKD, the secondary hyperparathyroidism was assessed in a large cohort by parathyroid hormone and OC as marker of bone turnover. The higher levels of OC reported in post-renal transplant patients with CKD stage IV versus those with CKD III [46] are in agreement with the findings of Holden et al. [9], even when they assessed \%ucOC. In addition, post-renal transplant patients with higher levels of serum OC showed an increase bone turnover [50]. Contrary, lower OC levels were found in CKD stages IV-V than healthy controls, with a non-significant decreasing 
trend as CKD advanced [45]. The apparent conflicting results obtained by Gluba-Brzózka et al. [45] came from the fact that no statistical significance has been reached when OC was compared to the healthy population.

In terms of the relationship between OC and kidney damage markers, Holden et al. [9] found a strong positive association among \%ucOC, stage of CKD and urinary loss of proteins. Circulating OC was inversely correlated with eGFR in patients with CKD stage II-IV [49], as well as with creatinine clearance in older adults without CKD [47]. Although these correlations have been found, they should be analyzed through the perspective of the coexistence of secondary hyperparathyroidism, impairment of glomerular filtration and age-related co-morbidities (bone diseases, VC, cancer, and chronic inflammation). All these determinants could influence the circulating OC levels, complicating the interpretation of the OC results in CKD patients with comorbidities.

There are also interesting findings from cross-sectional studies that open new research directions especially because OC is thought to have hormonal functions. In this respect, higher leptin levels were associated with lower levels of $\mathrm{OC}$ in a large cohort of post renal transplant patients [48]. In patients with CKD stage II-IV, higher adiponectin levels were associated with increased serum OC levels, showing a possible OC regulation on pancreatic $\beta$-cell proliferation and adipocyte gene expression, causing an increase of insulin secretion and consequently adiponectin synthesis [49]. Therefore, adipose tissue seems to exert an effect on bone tissue, perhaps mediated via leptin and adiponectin secretion. Kovesdy et al. [48] assumed that leptin, a hormone secreted by adipose tissue, probably influences the bone turnover directly by modulating osteoblast differentiation, but also indirectly through the activation of hypothalamic $\beta$-adrenergic system and up-regulation of $\beta$-adrenergic receptors in bone cells.

\subsubsection{Osteocalcin in Dialysis and Interventional Studies}

Lower serum OC levels were strongly associated with higher incidence of cardiovascular events in HD patients [43], being also considered a possible diagnostic tool for adynamic bone disease in predialysis patients with ESRD [44]. In a cross-sectional study on HD patients with higher bone turnover, serum OC was higher, while in HD patients with mineralization defects were lower [53], suggesting a possible use of circulating OC as marker of bone formation in HD patients. Moreover, fetuin-A, a systemic calcification inhibitor and modulator of bone metabolism, was negatively associated with serum OC levels in HD patients with high bone turnover [54]. In addition, in line with its hormonal effects, increased levels of serum ucOC were inversely correlated with indices of glucose metabolism in HD patients [55].

Interestingly, serum OC was not associated with bone mineral density in patients with peritoneal dialysis [56]. However, lower OC levels were associated with increased incidence of VC, while serum OC levels were inversely correlated with aortic pulse wave velocity $[57,58]$.

With respect to carboxylation status of OC, surprisingly, both the ucOC and cOC levels were higher in HD patients [10]. There are two possible theories for this finding: either circulating OC fragments are retained in uremic serum of $\mathrm{HD}$ patients or the associated ESRD enhanced bone turnover, leading to an overall increase in OC synthesis and consequently to high levels of both cOC and ucOC.

Studies on OC related to treatments and drug administration are summarized in Table 6. 
Table 6. Interventional studies on OC.

\begin{tabular}{|c|c|c|c|}
\hline Reference & $\begin{array}{c}\text { Number of Subjects and } \\
\text { Pathology }\end{array}$ & Drug/Treatment & Findings \\
\hline Krause et al. 2018 [51] & 22 patients, $\mathrm{HD}$ & $\begin{array}{l}\text { Partial body cutaneous exposure } \\
\text { to UVB radiation }\end{array}$ & Reduced in serum \\
\hline Ma et al. 2017 [52] & 31 patients with $\mathrm{HD}$ & Partial parathyroidectomy & Reduced in serum \\
\hline Kettler et al. 2018 [59] & $\begin{array}{l}1059 \text { patients with } \\
\text { hyperphosphatemic CKD }\end{array}$ & $\begin{array}{l}\text { Sucroferric oxyhydroxide, } \\
\text { Sevelamer carbonate (phosphate } \\
\text { binders) }\end{array}$ & Increased in serum \\
\hline Mirfatahi et al. 2018 [60] & 34 patients with HD & $\begin{array}{l}\text { Flaxseed oil } \\
\text { (omega-3 fatty acid and } \\
\text { alpha-linolenic acid) }\end{array}$ & $\begin{array}{l}\text { No significant change in } \\
\text { serum }\end{array}$ \\
\hline Greeviroj et al. 2018 [61] & $\begin{array}{l}\text { 10,031 patients with HD } \\
\text { (meta-analysis) }\end{array}$ & Cinacalcet (calcimimetic) & $\begin{array}{c}\text { No significant change in } \\
\text { serum }\end{array}$ \\
\hline Schwarz et al. 2011 [62] & $\begin{array}{l}58 \text { patients with } \\
\text { hyperparathyroidism after renal } \\
\text { transplant }\end{array}$ & Cinacalcet & $\begin{array}{l}\text { No significant change in } \\
\text { serum }\end{array}$ \\
\hline Hirai et al. 2010 [63] & 47 patients with HD & Cinacalcet & $\begin{array}{c}\text { No significant change in } \\
\text { serum }\end{array}$ \\
\hline $\begin{array}{l}\text { Shigematsu et al. } 2010 \\
\text { [64] }\end{array}$ & 145 patients with HD & $\begin{array}{l}\text { Lanthanum carbonate } \\
\text { (phosphate binder) }\end{array}$ & $\begin{array}{c}\text { No significant change in } \\
\text { serum }\end{array}$ \\
\hline Malluche et al. 2008 [65] & 65 patients with HD & Lanthanum carbonate & $\begin{array}{c}\text { No significant change in } \\
\text { serum }\end{array}$ \\
\hline Gomes et al. 2017 [66] & $\begin{array}{l}39 \text { patients with non-dialysis } \\
\text { dependent CKD }\end{array}$ & Aerobic exercise & $\begin{array}{l}\text { No significant change in } \\
\text { serum for cOC and uCOC }\end{array}$ \\
\hline Watanabe et al. 2017 [67] & Osteoclast cell culture in mice & $\begin{array}{l}\text { Indoxyl sulfate } \\
\text { (uremic toxin) }\end{array}$ & Suppress expression \\
\hline $\begin{array}{l}\text { Gauthier-Bastien et al. } \\
2014 \text { [68] }\end{array}$ & $\begin{array}{l}\text { Induced CKD by subtotal } \\
\text { nephrectomy in mice }\end{array}$ & $\begin{array}{l}\text { Calcium and phosphate diet, } \\
\text { with vitamin D supplementation }\end{array}$ & $\begin{array}{c}\text { De novo expression in } \\
\text { VSMCs }\end{array}$ \\
\hline Troib et al. 2016 [69] & $\begin{array}{l}\text { Induced CKD by subtotal } \\
\text { nephrectomy in rats }\end{array}$ & Endurance exercise & $\begin{array}{l}\text { Improved expression in } \\
\text { epiphyseal growth plate }\end{array}$ \\
\hline
\end{tabular}

\subsection{Gas6 in Kidney Disease}

The TAM receptors and Gas6 as ligand are essential modulators of complex metabolic processes, ranging from vascular atherosclerosis, thrombosis to inflammation, but few studies are published on Gas6-Axl pathway in humans with CKD [70].

\subsubsection{Gas6 in CKD and Acute Kidney Disease}

In patients with HD and CKD, Gas6 levels were found to be elevated and inversely associated with eGFR [70]. The most likely reason for the increase of Gas6 is related to its role in endothelial cell function. In specific conditions, such as inflammation and repair, Gas6 and its receptors are expressed by leukocytes and endothelial cells. A study in mice showed that Gas6 is essential in promoting and accelerating the sequestration of leukocytes and platelets in damaged endothelium [124]. Weiner et al. [125] emphasized that endothelial cells in CKD are exposed to specific stress leading to accelerated vascular disease and high cardiovascular mortality. Therefore, a constellation of factors acting on endothelial cells, such as structural degeneration, endothelial damage and oxidative stress, may provoke vascular disruption and inflammation in glomerular capillaries but also in large vessels, influencing the evolution of CKD and peripheral vascular disease, consequently leading to increased Gas6 levels.

Elevated plasma Gas6 levels were also found in patients with Hantaan virus that causes hemorrhagic fever, being directly correlated with the disease severity [71]. This increase is probably attributed to the incurring acute renal injury as the disease takes its course, higher levels being released from endothelial cells into circulation as renal lesions advance.

Patients with DN and micro-/macroalbuminuria were found to have significantly lower Gas6 levels compared to DN patients with normoalbuminuria, and higher Gas6 levels were associated with lower risk for DN [72]. The authors did not provide any hypothesis for those important findings, but 
they clearly emphasized that Gas6 could be involved in the development and progression of DN, being a potential marker for its early diagnosis.

\subsubsection{Gas6 in Renal Cancer}

An additional field in which Gas6 shows potential interest is renal cancer, more specifically in clear cell renal carcinoma (CCRC), the most common type of renal cell carcinoma. Inactivation of the Gas6/Axl pathway in CCRC was shown to reverse metastatic and invasive cell phenotypes [73], while Gas6 mediated activation of CCRC cells decreased their viability and migratory capacity [74]. CCRC patients with lower levels of tumor Axl receptor expression and higher levels of tumor Gas6 showed significantly increased survival rate [75]. It was also found that Gas6 activation of Axl was enhanced in the presence of Sunitinib (a tyrosine kinase receptor inhibitor), which might contribute to CCRC cell chemoresistance [76]. Based on the above-mentioned CCRC studies, we can draw the following conclusions: Gas6-mediated activation of Axl in CCRC cells leads to receptor down-regulation and decreased migratory capacity cell-viability, but the Gas6/Axl pathway has no effect on invasion.

\subsubsection{Gas6 in Experimental Studies}

The majority of studies concerning Gas6 are still at the level of fundamental research. However, the implication of Gas6 in VC and apoptosis has been supported lately in few research papers. In this respect, VSMCs treated with iron citrate showed increased VC due to down-regulation of Gas6/Axl pathway with subsequent prevention of apoptosis in rats [77], while mice treated with aldosterone showed increased Gas6 expression [78]. Administration of Raloxifene (an estrogen receptor modulator) was found to significantly decrease Gas6 levels in aortic valves of rats, with down-regulation of Gas6/Axl pathway and decreased aortic valve calcification [79].

Recombinant mouse Gas6 reduced vascular calcification in rats and showed improvement of acute kidney injury with increased survival rate in septic mice [80,81]. Recombinant mouse Gas6 administration in mice with renal ischemia also showed reduced apoptosis and inflammation of renal tissue [82]. The results from these studies strongly suggest a beneficial role of Gas6 in kidney disease, at least in the mammal models. Gas6 was found to be detectable in the urine of mice with podocyte proliferation in response to acute kidney injury [83]. Renal tubular Gas6 expression was also found to increase in mice under treatment with Captopril [84], Gas6 levels being higher in the early stages of salt-dependent hypertension in rats [85].

Even if inconsistent results have been reported on the implication of Gas6 in kidney disease, we can assume that the pathways of Gas6 and Axl are complex and most likely context-specific, thus their role in $\mathrm{VC}$, apoptosis and inflammation of renal tissue can be challenging.

\subsection{GRP in Kidney Disease}

Although there are several studies on GRP with respect to other pathologies, the field of kidney research is still at an early stage. Only one study met our inclusion criteria for GRP, the newest member of the VKDPs family [86].

Serum calciprotein particles are recently discovered colloidal protein-mineral particles, mainly composed of calcium, phosphate, fetuin-A and calcium-binding proteins, which are believed to possess a defense mechanism against calcium-phosphate precipitation in blood [126]. These particles were found to have lower concentration of GRP in patients with CKD stage V, while in vitro, the formation of calcium-phosphate crystals was greatly reduced by incubation with $\gamma$-carboxylated GRP [86]. Even if the particles were associated to CKD calcification predisposition, the precise information about their structure, packaging process and function are missing. Knowing that calciprotein particles are key players for the high calcification potential of CKD uremic serum, Viegas et al. [86] demonstrated, both in vivo and in vitro, that GRP, as a constitutive component of calciprotein particles, is an important inhibitory factor to halt systemic and local calcification. They also indicated the pathogenic pathway of these particles in uremic serum, proving that calciprotein particles with lower levels of GRP 
and fetuin-A can induce calcification of VSMCs by promoting osteochondrogenic differentiation and inflammation.

The discovery of serum calciprotein particles opens new research horizons for other VKDPs that might enter in their assembly, thus the ratio between the percentages of each VKDP could demonstrate similarities with the interplay found in lipoprotein particles.

\section{Discussions}

Taking into consideration the outcomes of the studies encompassed in this review, it is necessary to raise few topics that could be of interest for future research.

\subsection{The Interplay between Molecular Charge and Weight Could Play a Role in Glomerular Filtration of VKDPs}

Serum concentrations of VKDPs are influenced by multiple determinants ranging from vitamin $\mathrm{K}$ status, presence of underlying metabolic and cardiovascular disease to impaired kidney function. The exact mechanism of how CKD contributes to variations of circulating VKDPs levels is not yet entirely understood. Considering the existence of an impairment in glomerular filtration, and tubular injuries being less frequently invoked in patients with CKD [127], we hypothesize that variations in circulating levels of VKDPS are most likely influenced by glomerular filtration. Two essential aspects of VKDPs structure may account in this interplay: molecular weight and molecular charge.

The glomerular membrane is equipped with pores that physiologically do not allow the filtration of serum proteins. Moreover, due to the presence of numerous heparan sulfate proteoglycan molecules in its structure, the glomerular membrane displays a net negative charge [128] that creates an effect of electrostatic repelling with similarly charged proteins. VKDPs possess a variety of Glu and Ser residues which in turn become carboxylated and/or phosphorylated, respectively. These post-translational modifications may allow VKDPs to exhibit a greater negative charge, thus a more enhanced repelling effect at the glomerular membrane level.

Both MGP and GRP have similar molecular weights of $10.6 \mathrm{kDa}$ and $10.2 \mathrm{kDa}$, respectively $[87,117]$. On the other hand, OC is the smallest among the four VKDPs with a size of 5.6 kDa [97], while Gas6 is the largest, weighing $75 \mathrm{kDa}$ [109], with a similar molecular weight to albumin (around $66 \mathrm{kDa}$ ) [129], which can pass into urine leading to albuminuria in cases of glomerular dysfunction [72]. There are no comparative studies on glomerular filtration with respect to the size of the four molecules of VKDPs. However, two studies tested filtration through dialysis membranes, but only MGP was assessed among the four VKDPs [29,30]. Both studies observed that, after incubation with conventional HF serum, VSMCs produced significantly higher concentrations of MGP than VSMCs under HCO, MCO and $\mathrm{HRO}$ serums. It can be concluded that the type of dialyzer influenced the protein expression pattern of VSMCs.

While the molecular weights for MGP and GRP are similar, their net molecular charges vary greatly due to the different number of Gla residues. In contrast to the highly carboxylated GRP, which accounts for a total of sixteen Gla residues, MGP has five Gla residues in its fully carboxylated conformation $[87,117]$. Gas6 has only one N-terminal Gla domain with eleven potential Gla residues, while OC contains three Gla residues [97,109].

Considering the previously mentioned molecular characteristics, the serum levels of VKDPs should vary considerably in context of CKD progression because glomerular filtration becomes less restrictive as CKD progresses. Smaller molecules, e.g., OC, should be filtered more rapidly, compared to larger ones, such as Gas6. Molecular charge should also play a distinctive role in influencing each protein's capacity to cross the glomerular barrier. Another aspect worth considering is that the status of carboxylation and phosphorylation for each VKDP contributes to its net negative charge, which results in greater electrostatic repelling for the fully carboxylated and phosphorylated species at the glomerular level.

Instead, VKDPs act differently in terms of circulating modifications. Serum dp-ucMGP levels were found to be elevated in CKD patients $[17,18]$, as well as in HD patients $[12,19,20]$, but ucMGP levels 
were decreased in HD patients $[25,26]$. In addition, serum GRP levels were decreased in advanced stages of CKD [86]. Serum OC levels were found elevated in more advanced CKD of post renal transplant patients [46], as well as both cOC and ucOC in HD patients [10]. Gas6 levels were inversely correlated with eGFR, serum levels of Gas6 increasing as CKD stage became more advanced [70].

As mentioned above, vitamin K insufficiency was found to be present in CKD and HD patients $[9,10]$ due to an apparent lower vitamin K intake [10]. Vitamin K insufficiency could be admitted to be present in both CKD and HD patients to approximately the same extent considering that vitamin $\mathrm{K}$ is lipophilic and cannot be cleared by dialysis. Accordingly, the circulating levels of uncarboxylated species should increase in these patients, thus VKDPs would be less negatively charged, leading to lower glomerular repelling and consequently to lower circulating levels. Only the decrease of circulating ucMGP $[25,26]$ and GRP (although its uncarboxylated conformation was not assessed) [86] supports this hypothesis, whereas increased dp-ucMGP and ucOC are against $[10,17,18]$. There is also an alternative explanation, as follows: due to the lack of phospho-Ser residues and therefore less attractiveness to calcification areas, dp-ucMGP would be released more rapidly than ucMGP into circulation, leading to higher serum dp-ucMGP levels.

If we were to introduce solubility in the equation, the overall picture would become more complicated. As mentioned in the Section "Functional and Molecular Background", MGP and GRP are insoluble in water, only OC being water-soluble. According to our knowledge, there are no human studies published so far on the assessment of VKDPs in urine. However, a strong positive correlation between plasma Gas6 levels and urinary Gla residues in patients with liver diseases has been found [130]. In addition, Gas6 was detected in the urine of mice with podocyte proliferation in response to acute kidney injury [83].

In context of normal renal function, OC and its fragments are rapidly cleared by the kidney, contributing to the pool of urinary Gla residues. Rathore et al. [131] supported the idea that OC fragments accumulate and are detectable in renal failure, proposing urinary $\mathrm{OC}$ as future marker of bone turnover regardless of its limitations as age related renal impairment or higher pre-analytical variability compared to OC serum assays.

Overall, to test the hypothesis of glomerular repelling and its interplay with the size of VKDPs, future studies should analyze and compare the circulating concentration to the urinary output for each VKDP.

\subsection{The Relationship between the Etiologies of CKD and the Modifications of Circulating VKDPs}

Because the pathology of CKD encompasses multiple etiologies such as DN, nephrolithiasis, autoimmune nephritis and others, we must raise the question whether the variation in circulating VKDPs levels are caused by the impaired renal function itself or by the underlying etiologies of CKD.

Most of the studies either did not identify the specific etiology of the kidney disease $[9,14,17,18$, $45,46,80,86]$ or in the study protocol the authors included multiple etiologies that were all considered as CKD $[15,38]$ Moreover, the statistics used for the assessment of association between VKDPs and etiologies of CKD are missing. Most of the studies found associations between VKDPs and CKD progression or parameters of kidney damage $[9,15,41]$, but did not perform any correlations with the etiology itself or at least with subgroup of etiologies. This may suggest that circulating VKDP levels are in fact influenced by the accompanying renal impairment, rather than by distinct etiologies responsible for CKD.

Over the past ten years, we found only two studies that actually analyzed VKDPs in a specific etiology related to CKD [27,72]. In the first study, lower Gas6 levels were found in patients with DN and micro-/macroalbuminuria compared to DN patients with normoalbuminuria, higher Gas6 levels being associated with lower risk for DN [72]. However, Roumeliotis et al. [27] found no association between plasma dp-ucMGP levels and calcified carotid intima media thickness in patients with DN.

Due to missing data, a clear conclusion cannot be confidently drawn. However, since the modifications of circulating VKDPs could also be interpreted as an epiphenomenon of the etiology 
itself, future longitudinal studies are warranted to validate the etiology as a determinant among others that satellite CKD, such as: vitamin K insufficiency, secondary hyperparathyroidism or impairment of glomerular filtration.

\subsection{VKDPs as Potential Markers in Kidney Disease}

The outcomes of studies encompassed in this review can show us the utility of VKDPs as screening tools in kidney disease. It has been reported that circulating levels of dp-ucMGP [17,18], Gas6 [70], OC and \%ucOC $[9,46]$ increased with the advance of CKD stages. In this respect, we can rule out GRP, because there is only one study performed in patients with CKD without referring to disease progression [86].

Apart from the fact that circulating dp-ucMGP was demonstrated to increase with CKD progression, reaching a peak in patients with HD, dp-ucMGP levels were also positively associated with the severity of VC in patients with CKD [17]. In line with this evidence, serum levels of ucMGP were inversely associated with the extent of VD in HD patients [25]. On the other hand, phosphorylated MGP conformations had generally low circulating levels in patients with highly calcified CKD, thus limiting their use as a biomarker [17].

It is not clear if serum MGP levels, mainly attributed to the inactive dp-ucMGP, are influenced directly by kidney disfunction or more so by vitamin $\mathrm{K}$ insufficiency. The cross-sectional and cohort studies only assessed dp-ucMGP levels in CKD, but not serum levels of total MGP [94]. The increase in dp-ucMGP levels might only be a shift in the ratio of active versus inactive forms of MGP, with total MGP levels remaining unchanged. However, there are also longitudinal studies which validated the relationship between dp-ucMGP and HD, concluding that lower levels of circulating dp-cMGP could be designated as possible predictor of mortality in HD patients [12].

Moreover, different responses after vitamin K supplementation were demonstrated for dp-ucMGP and ucMGP. The circulating dp-ucMGP levels declined after vitamin $K_{2}$ supplementation $[15,38]$ in CKD patients, while vitamin $K_{1}$ supplementation was not associated with circulating ucMGP levels in HD patients [39]. Therefore, ucMGP level was a weak surrogate for functional vitamin $\mathrm{K}_{1}$ deficiency, while circulating dp-uc MGP responded in a correlated manner with the supplementation of vitamin $\mathrm{K}_{2}$, thus reflecting vitamin $\mathrm{K}_{2}$ status.

If we discuss about the association of MGP with kidney damage assessed by common parameters of glomerular dysfunction, controversial results have been reported considering whether the levels of dp-ucMGP and ucMGP were increased or decreased. In patients with coronary artery disease, lower circulating ucMGP levels were correlated with a decrease in eGFR, but albumin-to-creatinine ratio remained unaffected [41]. In contrast, dp-ucMGP levels were progressively increased with decreasing renal function assessed by eGFR [18]. This outcome was in congruence with the findings of Schurgers et al. [17] according to which glomerular dysfunction was the only independent determinant for higher plasma levels of dp-ucMGP. In addition, a positive association was found between circulating dp-ucMGP and proteinuria in patients with advanced CKD [15]. Kurnatowska et al. [15] supported the following two conflicting deductions: either kidney damage is a key determinant of vitamin $\mathrm{K}$ deficiency in vasculature, or poor vitamin $\mathrm{K}$ status could be a risk factor for kidney dysfunction. Logically, a decline of vitamin $\mathrm{K}$ status comes first, resulting in an increased general predisposition for calcification, lithiasis and consequently impaired kidney function. To validate these theories further longitudinal studies are needed.

The presented data allow us to support the following conclusions: high dp-ucMGP levels could be considered a surrogate marker for VC and cardiovascular risk in CKD patients, reflecting a poor vitamin $\mathrm{K}$ status [17]. On the contrary, circulating ucMGP do not reflect vitamin $\mathrm{K}$ status and warrant future study to validate its usefulness as a marker for VC in CKD. In addition, the present literature does not lend support for Gas6 to be currently designated as marker for VC or vitamin K status in CKD, but it showed potential as proxy for impaired glomerular filtration in CKD or improving early diagnosis of DN [72]. 
While in the previously mentioned studies dp-ucMGP levels demonstrated an increase related to $C K D$ progression, there are divergent views on the variations of circulating $O C$. Gluba-Brzózka et al. [45] found that OC levels increased in early stages of CKD and progressively decreased as the disease advanced. Contrariwise, higher circulating OC was reported in post renal transplant patients with CKD stage IV compared to CKD stage III [46]. In addition, the same pattern of serum modification was noticed for \%ucOC, higher levels being found as CKD progresses [9]. Even if Holden et al. [9] reported consistent associations of \%ucOC with CKD stage and urinary loss of proteins, the authors emphasized that \%ucOC is not a perfect marker for vitamin $\mathrm{K}$ status in more advanced CKD due to the underlying secondary hyperparathyroidism, which leads to increased bone turnover, all this in the context of a diminished glomerular filtration with consequent retention of $\mathrm{OC}$ fragments. The OC fragments are cleared mostly by the kidneys, so there is significant heterogeneity of circulating OC in patients with renal impairment, thus limiting the usefulness of OC as a marker of bone turnover.

Further study is also required to clarify why both serum ucOC and cOC levels were increased in HD patients [10]. The authors speculate that application of OC assessment in HD patients seems to be difficult and OC carboxylation might not be a useful marker for vitamin K status in patients with HD.

\section{Conclusions}

There is still a broad research area to cover with aspects related to the roles and molecular interactions of VKDPs. Although the relationship between the modifications of circulating VKDPs and the etiologies of CKD has not been sufficiently addressed, mounting evidence shows that VKDPs are useful tools to improve early diagnosis, monitor progression or identify complications of CKD. Future studies on the assessment of VKDPs in terms of blood/urine ratio, as well as the use of mediation analyses to study the influence of eGRF in the relationship between VKDPs and CKD etiology are needed to emphasize the added benefit of VKDPs. In this respect, dp-ucMGP is more likely to become a suitable marker for detection of VC and cardiovascular risk in CKD patients.

Even if substantial efforts are still entailed to warrant the accurate validation and reproducibility for clinical implementation, researchers should stay abreast of the recent literature as VKDPs could become a common screening tool for different CKD settings in the near future.

Author Contributions: Writing—original draft, V.P.F. and M.F.; Writing—review and editing, C.N.S., T.I., A.J.v.B. and A.M.C.

Funding: This work was supported by a grant of Ministry of Research and Innovation, CNCS-UEFISCDI, project number PN-III-P4-ID-PCCF-2016-0016, within PNCDI III.

Conflicts of Interest: The authors declare no conflict of interest.

\section{Abbreviations}

$\begin{array}{ll}\text { \%ucOC } & \text { Percentage of total osteocalcin that is uncarboxylated } \\ \text { CCRC } & \text { Clear cell renal carcinoma } \\ \text { CKD } & \text { Chronic kidney disease } \\ \text { cOC } & \text { Carboxylated osteocalcin } \\ \text { cMGP } & \text { Carboxylated matrix Gla protein } \\ \text { DN } & \text { Diabetic nephropathy } \\ \text { dp-cMGP } & \text { Dephospho-carboxylated matrix Gla protein } \\ \text { dp-ucMGP } & \text { Dephospho-uncarboxylated matrix Gla protein } \\ \text { ESRD } & \text { End-stage renal disease } \\ \text { Gas6 } & \text { Growth-arrest specific protein } 6 \\ \text { Gla } & \text { Carboxy glutamic acid } \\ \text { Glu } & \text { Glutamic acid } \\ \text { GRP } & \text { Gla-rich protein }\end{array}$




$\begin{array}{ll}\text { HCO } & \text { High Cut-Off dialysis } \\ \text { HD } & \text { Hemodialysis } \\ \text { HF } & \text { Conventional High Flow dialysis } \\ \text { HRO } & \text { High Retention Onset dialysis } \\ \text { MCO } & \text { Medium Cut-Off dialysis } \\ \text { MDCK } & \text { Madin-Darby Canine Kidney } \\ \text { MGP } & \text { Matrix Gla protein } \\ \text { OC } & \text { Osteocalcin } \\ \text { p-cMGP } & \text { Phospho-carboxylated matrix Gla protein } \\ \text { Ser } & \text { Serine } \\ \text { t-ucMGP } & \text { Total-uncarboxylated matrix Gla protein } \\ \text { ucMGP } & \text { Uncarboxylated matrix Gla protein } \\ \text { ucOC } & \text { Uncarboxylated osteocalcin } \\ \text { VC } & \text { Vascular calcification } \\ \text { VKDPs } & \text { Vitamin K dependent proteins } \\ \text { VSMCs } & \text { Vascular smooth muscle cells }\end{array}$

\section{References}

1. Lopez-Giacoman, S.; Madero, M. Biomarkers in chronic kidney disease, from kidney function to kidney damage. World J. Nephrol. 2015, 4, 57-73. [CrossRef]

2. Rysz, J.; Gluba-Brzózka, A.; Franczyk, B.; Jabłonowski, Z.; Ciałkowska-Rysz, A. Novel Biomarkers in the Diagnosis of Chronic Kidney Disease and the Prediction of Its Outcome. Int. J. Mol. Sci. 2017, 18, 1702. [CrossRef] [PubMed]

3. Chatrou, M.L.L.; Reutelingsperger, C.P.; Schurgers, L.J. Role of vitamin K-dependent proteins in the arterial vessel wall. Hamostaseologie 2011, 31, 251-257. [CrossRef] [PubMed]

4. Schurgers, L.J.; Dissel, P.E.; Spronk, H.M.; Soute, B.A.; Dhore, C.R.; Cleutjens, J.P.; Vermeer, C. Role of vitamin $\mathrm{K}$ and vitamin K-dependent proteins in vascular calcification. Z. Kardiol. 2001, 90 (Suppl. 3), 57-63. [CrossRef] [PubMed]

5. London, G.M.; Guérin, A.P.; Marchais, S.J.; Métivier, F.; Pannier, B.; Adda, H. Arterial media calcification in end-stage renal disease: Impact on all-cause and cardiovascular mortality. Nephrol. Dial. Transplant. 2003, 18, 1731-1740. [CrossRef]

6. Stitt, T.N.; Conn, G.; Gore, M.; Lai, C.; Bruno, J.; Radziejewski, C.; Mattsson, K.; Fisher, J.; Gies, D.R.; Jones, P.F. The anticoagulation factor protein $\mathrm{S}$ and its relative, Gas6, are ligands for the Tyro 3/Axl family of receptor tyrosine kinases. Cell 1995, 80, 661-670. [CrossRef]

7. Varnum, B.C.; Young, C.; Elliott, G.; Garcia, A.; Bartley, T.D.; Fridell, Y.W.; Hunt, R.W.; Trail, G.; Clogston, C.; Toso, R.J. Axl receptor tyrosine kinase stimulated by the vitamin K-dependent protein encoded by growth-arrest-specific gene 6. Nature 1995, 373, 623-626. [CrossRef]

8. Davidsen, K.T.; Haaland, G.S.; Lie, M.K.; Lorens, J.B.; Engelsen, A.S.T. The Role of Axl Receptor Tyrosine Kinase in Tumor Cell Plasticity and Therapy Resistance. In Biomarkers of the Tumor Microenvironment: Basic Studies and Practical Applications; Akslen, L.A., Watnick, R.S., Eds.; Springer International Publishing: Cham, Switzerland, 2017; pp. 351-376.

9. Holden, R.M.; Morton, A.R.; Garland, J.S.; Pavlov, A.; Day, A.G.; Booth, S.L. Vitamins K and D status in stages 3-5 chronic kidney disease. Clin. J. Am. Soc. Nephrol. 2010, 5, 590-597. [CrossRef]

10. Cranenburg, E.C.M.; Schurgers, L.J.; Uiterwijk, H.H.; Beulens, J.W.J.; Dalmeijer, G.W.; Westerhuis, R.; Magdeleyns, E.J.; Herfs, M.; Vermeer, C.; Laverman, G.D. Vitamin K intake and status are low in hemodialysis patients. Kidney Int. 2012, 82, 605-610. [CrossRef] [PubMed]

11. Levey, A.S.; Eckardt, K.-U.; Tsukamoto, Y.; Levin, A.; Coresh, J.; Rossert, J.; De Zeeuw, D.; Hostetter, T.H.; Lameire, N.; Eknoyan, G. Definition and classification of chronic kidney disease: A position statement from Kidney Disease: Improving Global Outcomes (KDIGO). Kidney Int. 2005, 67, 2089-2100. [CrossRef] [PubMed]

12. Schlieper, G.; Westenfeld, R.; Krüger, T.; Cranenburg, E.C.; Magdeleyns, E.J.; Brandenburg, V.M.; Djuric, Z.; Damjanovic, T.; Ketteler, M.; Vermeer, C.; et al. Circulating nonphosphorylated carboxylated matrix gla protein predicts survival in ESRD. J. Am. Soc. Nephrol. 2011, 22, 387-395. [CrossRef] 
13. Riphagen, I.J.; Keyzer, C.A.; Drummen, N.E.A.; de Borst, M.H.; Beulens, J.W.J.; Gansevoort, R.T.; Geleijnse, J.M.; Muskiet, F.A.J.; Navis, G.; Visser, S.T.; et al. Prevalence and Effects of Functional Vitamin K Insufficiency: The PREVEND Study. Nutrients 2017, 9, 1334. [CrossRef]

14. Thamratnopkoon, S.; Susantitaphong, P.; Tumkosit, M.; Katavetin, P.; Tiranathanagul, K.; Praditpornsilpa, K.; Eiam-Ong, S. Correlations of Plasma Desphosphorylated Uncarboxylated Matrix Gla Protein with Vascular Calcification and Vascular Stiffness in Chronic Kidney Disease. Nephron 2017, 135, 167-172. [CrossRef] [PubMed]

15. Kurnatowska, I.; Grzelak, P.; Masajtis-Zagajewska, A.; Kaczmarska, M.; Stefańczyk, L.; Vermeer, C.; Maresz, K.; Nowicki, M. Plasma Desphospho-Uncarboxylated Matrix Gla Protein as a Marker of Kidney Damage and Cardiovascular Risk in Advanced Stage of Chronic Kidney Disease. Kidney Blood Press. Res. 2016, 41, 231-239. [CrossRef]

16. Meuwese, C.L.; Olauson, H.; Qureshi, A.R.; Ripsweden, J.; Barany, P.; Vermeer, C.; Drummen, N.; Stenvinkel, P. Associations between Thyroid Hormones, Calcification Inhibitor Levels and Vascular Calcification in End-Stage Renal Disease. PLoS ONE 2015, 10, e0132353. [CrossRef]

17. Schurgers, L.J.; Barreto, D.V.; Barreto, F.C.; Liabeuf, S.; Renard, C.; Magdeleyns, E.J.; Vermeer, C.; Choukroun, G.; Massy, Z.A. The circulating inactive form of matrix gla protein is a surrogate marker for vascular calcification in chronic kidney disease: A preliminary report. Clin. J. Am. Soc. Nephrol. 2010, 5, 568-575. [CrossRef] [PubMed]

18. Puzantian, H.; Akers, S.R.; Oldland, G.; Javaid, K.; Miller, R.; Ge, Y.; Ansari, B.; Lee, J.; Suri, A.; Hasmath, Z.; et al. Circulating Dephospho-Uncarboxylated Matrix Gla-Protein Is Associated with Kidney Dysfunction and Arterial Stiffness. Am. J. Hypertens. 2018, 31, 988-994. [CrossRef] [PubMed]

19. Fain, M.E.; Kapuku, G.K.; Paulson, W.D.; Williams, C.F.; Raed, A.; Dong, Y.; Knapen, M.H.J.; Vermeer, C.; Pollock, N.K. Inactive Matrix Gla Protein, Arterial Stiffness, and Endothelial Function in African American Hemodialysis Patients. Am. J. Hypertens. 2018, 31, 735-741. [CrossRef] [PubMed]

20. Westenfeld, R.; Krueger, T.; Schlieper, G.; Cranenburg, E.C.M.; Magdeleyns, E.J.; Heidenreich, S.; Holzmann, S.; Vermeer, C.; Jahnen-Dechent, W.; Ketteler, M.; et al. Effect of vitamin K2 supplementation on functional vitamin K deficiency in hemodialysis patients: A randomized trial. Am. J. Kidney Dis. 2012, 59, 186-195. [CrossRef] [PubMed]

21. Mansour, A.G.; Hariri, E.; Daaboul, Y.; Korjian, S.; El Alam, A.; Protogerou, A.D.; Kilany, H.; Karam, A.; Stephan, A.; Bahous, S.A. Vitamin K2 supplementation and arterial stiffness among renal transplant recipients-a single-arm, single-center clinical trial. J. Am. Soc. Hypertens. 2017, 11, 589-597. [CrossRef]

22. Jansz, T.T.; Neradova, A.; van Ballegooijen, A.J.; Verhaar, M.C.; Vervloet, M.G.; Schurgers, L.J.; van Jaarsveld, B.C. The role of kidney transplantation and phosphate binder use in vitamin K status. PLoS ONE 2018, 13, e0203157. [CrossRef]

23. Boxma, P.Y.; van den Berg, E.; Geleijnse, J.M.; Laverman, G.D.; Schurgers, L.J.; Vermeer, C.; Kema, I.P.; Muskiet, F.A.; Navis, G.; Bakker, S.J.L.; et al. Vitamin k intake and plasma desphospho-uncarboxylated matrix Gla-protein levels in kidney transplant recipients. PLoS ONE 2012, 7, e47991. [CrossRef]

24. Keyzer, C.A.; Vermeer, C.; Joosten, M.M.; Knapen, M.H.J.; Drummen, N.E.A.; Navis, G.; Bakker, S.J.L.; de Borst, M.H. Vitamin K status and mortality after kidney transplantation: A cohort study. Am. J. Kidney Dis. 2015, 65, 474-483. [CrossRef] [PubMed]

25. Cranenburg, E.C.M.; Brandenburg, V.M.; Vermeer, C.; Stenger, M.; Mühlenbruch, G.; Mahnken, A.H.; Gladziwa, U.; Ketteler, M.; Schurgers, L.J. Uncarboxylated matrix Gla protein (ucMGP) is associated with coronary artery calcification in haemodialysis patients. Thromb. Haemost. 2009, 101, 359-366.

26. Shroff, R.C.; Shah, V.; Hiorns, M.P.; Schoppet, M.; Hofbauer, L.C.; Hawa, G.; Schurgers, L.J.; Singhal, A.; Merryweather, I.; Brogan, P.; et al. The circulating calcification inhibitors, fetuin-A and osteoprotegerin, but not matrix Gla protein, are associated with vascular stiffness and calcification in children on dialysis. Nephrol. Dial. Transplant. 2008, 23, 3263-3271. [CrossRef] [PubMed]

27. Roumeliotis, S.; Roumeliotis, A.; Panagoutsos, S.; Giannakopoulou, E.; Papanas, N.; Manolopoulos, V.G.; Passadakis, P.; Tavridou, A. Matrix Gla protein T-138C polymorphism is associated with carotid intima media thickness and predicts mortality in patients with diabetic nephropathy. J. Diabetes Complic. 2017, 31, 1527-1532. [CrossRef] [PubMed] 
28. Schlieper, G.; Brandenburg, V.; Djuric, Z.; Damjanovic, T.; Markovic, N.; Schurgers, L.; Kruger, T.; Westenfeld, R.; Ackermann, D.; Haselhuhn, A.; et al. Risk factors for cardiovascular calcifications in non-diabetic Caucasian haemodialysis patients. Kidney Blood Press. Res. 2009, 32, 161-168. [CrossRef] [PubMed]

29. Willy, K.; Girndt, M.; Voelkl, J.; Fiedler, R.; Martus, P.; Storr, M.; Schindler, R.; Zickler, D. Expanded Haemodialysis Therapy of Chronic Haemodialysis Patients Prevents Calcification and Apoptosis of Vascular Smooth Muscle Cells in vitro. Blood Purif. 2018, 45, 131-138. [CrossRef]

30. Willy, K.; Hulko, M.; Storr, M.; Speidel, R.; Gauss, J.; Schindler, R.; Zickler, D. In Vitro Dialysis of Cytokine-Rich Plasma with High and Medium Cut-Off Membranes Reduces Its Procalcific Activity. Artif. Organs 2017, 41, 803-809. [CrossRef]

31. Khan, A.; Wang, W.; Khan, S.R. Calcium oxalate nephrolithiasis and expression of matrix GLA protein in the kidneys. World J. Urol. 2014, 32, 123-130. [CrossRef]

32. Lu, X.; Gao, B.; Yasui, T.; Li, Y.; Liu, T.; Mao, X.; Hirose, M.; Wu, Y.; Yu, D.; Zhu, Q.; et al. Matrix Gla protein is involved in crystal formation in kidney of hyperoxaluric rats. Kidney Blood Press. Res. 2013, 37, 15-23. [CrossRef]

33. Lomashvili, K.A.; Wang, X.; Wallin, R.; O'Neill, W.C. Matrix Gla protein metabolism in vascular smooth muscle and role in uremic vascular calcification. J. Biol. Chem. 2011, 286, 28715-28722. [CrossRef] [PubMed]

34. Lorenzen, J.M.; Martino, F.; Scheffner, I.; Bröcker, V.; Leitolf, H.; Haller, H.; Gwinner, W. Fetuin, matrix-Gla protein and osteopontin in calcification of renal allografts. PLoS ONE 2012, 7, e52039. [CrossRef]

35. Kramann, R.; Brandenburg, V.M.; Schurgers, L.J.; Ketteler, M.; Westphal, S.; Leisten, I.; Bovi, M.; Jahnen-Dechent, W.; Knüchel, R.; Floege, J.; et al. Novel insights into osteogenesis and matrix remodelling associated with calcific uraemic arteriolopathy. Nephrol. Dial. Transplant. 2013, 28, 856-868. [CrossRef]

36. Shroff, R.C.; McNair, R.; Figg, N.; Skepper, J.N.; Schurgers, L.; Gupta, A.; Hiorns, M.; Donald, A.E.; Deanfield, J.; Rees, L.; et al. Dialysis accelerates medial vascular calcification in part by triggering smooth muscle cell apoptosis. Circulation 2008, 118, 1748-1757. [CrossRef]

37. Wei, F.-F.; Drummen, N.E.A.; Thijs, L.; Jacobs, L.; Herfs, M.; Van't Hoofd, C.; Vermeer, C.; Staessen, J.A. Vitamin-K-Dependent Protection of the Renal Microvasculature: Histopathological Studies in Normal and Diseased Kidneys. Pulse Basel Switz. 2016, 4, 85-91. [CrossRef]

38. Kurnatowska, I.; Grzelak, P.; Masajtis-Zagajewska, A.; Kaczmarska, M.; Stefańczyk, L.; Vermeer, C.; Maresz, K.; Nowicki, M. Effect of vitamin K2 on progression of atherosclerosis and vascular calcification in nondialyzed patients with chronic kidney disease stages 3-5. Pol. Arch. Med. Wewn. 2015, 125, 631-640. [CrossRef] [PubMed]

39. Wyskida, K.; Żak-Gołąb, A.; Wajda, J.; Klein, D.; Witkowicz, J.; Ficek, R.; Rotkegel, S.; Spiechowicz, U.; Kocemba Dyczek, J.; Ciepał, J.; et al. Functional deficiency of vitamin $\mathrm{K}$ in hemodialysis patients in Upper Silesia in Poland. Int. Urol. Nephrol. 2016, 48, 765-771. [CrossRef] [PubMed]

40. Zhang, C.; Wang, S.; Zhao, S.; Zhang, X. Effect of lanthanum carbonate on coronary artery calcification and bone mineral density in maintenance hemodialysis patients with diabetes complicated with adynamic bone disease: A prospective pilot study. Medicine (Baltimore) 2017, 96, e8664. [CrossRef] [PubMed]

41. Parker, B.D.; Ix, J.H.; Cranenburg, E.C.M.; Vermeer, C.; Whooley, M.A.; Schurgers, L.J. Association of kidney function and uncarboxylated matrix Gla protein: Data from the Heart and Soul Study. Nephrol. Dial. Transplant. 2009, 24, 2095-2101. [CrossRef] [PubMed]

42. Van Ballegooijen, A.J.; Beulens, J.W. The Role of Vitamin K Status in Cardiovascular Health: Evidence from Observational and Clinical Studies. Curr. Nutr. Rep. 2017, 6, 197-205. [CrossRef]

43. Yamashita, T.; Okano, K.; Tsuruta, Y.; Akiba, T.; Nitta, K. Serum osteocalcin levels are useful as a predictor of cardiovascular events in maintenance hemodialysis patients. Int. Urol. Nephrol. 2013, 45, 207-214. [CrossRef]

44. Bervoets, A.R.J.; Spasovski, G.B.; Behets, G.J.; Dams, G.; Polenakovic, M.H.; Zafirovska, K.; Van Hoof, V.O.; De Broe, M.E.; D'Haese, P.C. Useful biochemical markers for diagnosing renal osteodystrophy in predialysis end-stage renal failure patients. Am. J. Kidney Dis. 2003, 41, 997-1007. [CrossRef]

45. Gluba-Brzózka, A.; Michalska-Kasiczak, M.; Franczyk, B.; Nocuń, M.; Toth, P.; Banach, M.; Rysz, J. Markers of increased atherosclerotic risk in patients with chronic kidney disease: A preliminary study. Lipids Health Dis. 2016, 15, 22. [CrossRef] [PubMed] 
46. Kovesdy, C.P.; Molnar, M.Z.; Czira, M.E.; Rudas, A.; Ujszaszi, A.; Sarvary, E.; Ambrus, C.; Szathmari, M.; Remport, A.; Mucsi, I. Diagnostic accuracy of serum parathyroid hormone levels in kidney transplant recipients with moderate-to-advanced CKD. Nephron Clin. Pract. 2011, 118, c78-c85. [CrossRef] [PubMed]

47. Yoshihara, A.; Hayashi, Y.; Miyazaki, H. Relationships among bone turnover, renal function and periodontal disease in elderly Japanese. J. Periodontal Res. 2011, 46, 491-496. [CrossRef]

48. Kovesdy, C.P.; Molnar, M.Z.; Czira, M.E.; Rudas, A.; Ujszaszi, A.; Rosivall, L.; Szathmari, M.; Covic, A.; Keszei, A.; Beko, G.; et al. Associations between serum leptin level and bone turnover in kidney transplant recipients. Clin. J. Am. Soc. Nephrol. 2010, 5, 2297-2304. [CrossRef] [PubMed]

49. Bacchetta, J.; Boutroy, S.; Guebre-Egziabher, F.; Juillard, L.; Drai, J.; Pelletier, S.; Richard, M.; Charrié, A.; Carlier, M.C.; Chapurlat, R.; et al. The relationship between adipokines, osteocalcin and bone quality in chronic kidney disease. Nephrol. Dial. Transplant. 2009, 24, 3120-3125. [CrossRef]

50. Falkiewicz, K.; Boratyńska, M.; Zmonarski, S.C.; Milewicz, A.; Patrzałek, D.; Biecek, P.; Klinger, M. Evolution of bone disease at 2 years after transplantation: A single-center study. Transplant. Proc. 2009, 41, 3063-3066. [CrossRef] [PubMed]

51. Krause, R.; Stange, R.; Roth, H.J.; Kaase, H.; Michalsen, A.; Holick, M.F. Partial Body UV Exposure in Chronic Kidney Disease and Extrarenal Vitamin D Metabolism. Anticancer Res. 2018, 38, 1217-1219. [PubMed]

52. Ma, L.; Zhao, S.; Li, Z. Effects of parathyroidectomy on bone metabolism in haemodialysis patients with secondary hyperparathyroidism. Scand. J. Clin. Lab. Investig. 2017, 77, 527-534. [CrossRef]

53. Keronen, S.; Martola, L.; Finne, P.; Burton, I.S.; Kauppila, L.; Kröger, H.; Larsson, T.E.; Honkanen, E. Bone histomorphometry and indicators of bone and mineral metabolism in wait-listed dialysis patients. Clin. Nephrol. 2016, 85, 127-134. [CrossRef]

54. Fedak, D.; Kuźniewski, M.; Dumnicka, P.; Kapusta, M.; Chmiel, G.; Solnica, B.; Sułowicz, W. Relationship between fetuin-A, bone turnover and inflammatory markers concentrations in serum of maintenance hemodialyzed patients. Przegl. Lek. 2016, 73, 799-804.

55. Okuno, S.; Ishimura, E.; Tsuboniwa, N.; Norimine, K.; Yamakawa, K.; Yamakawa, T.; Shoji, S.; Mori, K.; Nishizawa, Y.; Inaba, M. Significant inverse relationship between serum undercarboxylated osteocalcin and glycemic control in maintenance hemodialysis patients. Osteoporos. Int. 2013, 24, 605-612. [CrossRef]

56. Jeong, J.U.; Lee, H.K.; Kim, Y.J.; Kim, J.S.; Kang, S.S.; Kim, S.B. Nutritional markers, not markers of bone turnover, are related predictors of bone mineral density in chronic peritoneal dialysis patients. Clin. Nephrol. 2010, 74, 336-342. [CrossRef] [PubMed]

57. Avila, M.; Mora, C.; Prado, M.D.C.; Zavala, M.; Paniagua, R.; Mexican Collaborative Group. Osteoprotegerin Is the Strongest Predictor for Progression of Arterial Calcification in Peritoneal Dialysis Patients. Am. J. Nephrol. 2017, 46, 39-46. [CrossRef] [PubMed]

58. Krzanowski, M.; Janda, K.; Dumnicka, P.; Dubiel, M.; Stompór, M.; Kuśnierz-Cabala, B.; Grodzicki, T.; Sułowicz, W. Relationship between aortic pulse wave velocity, selected proinflammatory cytokines, and vascular calcification parameters in peritoneal dialysis patients. J. Hypertens. 2014, 32, 142-148. [CrossRef] [PubMed]

59. Ketteler, M.; Sprague, S.M.; Covic, A.C.; Rastogi, A.; Spinowitz, B.; Rakov, V.; Walpen, S.; Floege, J. Effects of sucroferric oxyhydroxide and sevelamer carbonate on chronic kidney disease-mineral bone disorder parameters in dialysis patients. Nephrol. Dial. Transplant. 2018, 1-8. [CrossRef] [PubMed]

60. Mirfatahi, M.; Imani, H.; Tabibi, H.; Nasrollahi, A.; Hedayati, M. Effects of Flaxseed Oil on Serum Bone Turnover Markers in Hemodialysis Patients: A Randomized Controlled Trial. Iran. J. Kidney Dis. 2018, 12, 215-222.

61. Greeviroj, P.; Kitrungphaiboon, T.; Katavetin, P.; Praditpornsilpa, K.; Eiam-Ong, S.; Jaber, B.L.; Susantitaphong, P. Cinacalcet for Treatment of Chronic Kidney Disease-Mineral and Bone Disorder: A Meta-Analysis of Randomized Controlled Trials. Nephron 2018, 139, 197-210. [CrossRef]

62. Schwarz, A.; Merkel, S.; Leitolf, H.; Haller, H. The effect of cinacalcet on bone remodeling and renal function in transplant patients with persistent hyperparathyroidism. Transplantation 2011, 91, 560-565. [CrossRef]

63. Hirai, T.; Nakashima, A.; Takasugi, N.; Yorioka, N. Association of nodular hyperplasia with resistance to cinacalcet therapy for secondary hyperparathyroidism in hemodialysis patients. Ther. Apher. Dial. 2010, 14, 577-582. [CrossRef]

64. Shigematsu, T.; Lanthanum Carbonate Research Group. Three-year extension study of lanthanum carbonate therapy in Japanese hemodialysis patients. Clin. Exp. Nephrol. 2010, 14, 589-597. [CrossRef] 
65. Malluche, H.H.; Siami, G.A.; Swanepoel, C.; Wang, G.H.; Mawad, H.; Confer, S.; Smith, M.; Pratt, R.D.; Monier-Faugere, M.-C.; SPD405-307 Lanthanum Carbonate Study Group. Improvements in renal osteodystrophy in patients treated with lanthanum carbonate for two years. Clin. Nephrol. 2008, 70, 284-295.

66. Gomes, T.S.; Aoike, D.T.; Baria, F.; Graciolli, F.G.; Moyses, R.M.A.; Cuppari, L. Effect of Aerobic Exercise on Markers of Bone Metabolism of Overweight and Obese Patients with Chronic Kidney Disease. J. Ren. Nutr. 2017, 27, 364-371. [CrossRef] [PubMed]

67. Watanabe, K.; Tominari, T.; Hirata, M.; Matsumoto, C.; Hirata, J.; Murphy, G.; Nagase, H.; Miyaura, C.; Inada, M. Indoxyl sulfate, a uremic toxin in chronic kidney disease, suppresses both bone formation and bone resorption. FEBS Open Bio 2017, 7, 1178-1185. [CrossRef]

68. Gauthier-Bastien, A.; Ung, R.-V.; Larivière, R.; Mac-Way, F.; Lebel, M.; Agharazii, M. Vascular remodeling and media calcification increases arterial stiffness in chronic kidney disease. Clin. Exp. Hypertens. 2014, 36, 173-180. [CrossRef] [PubMed]

69. Troib, A.; Guterman, M.; Rabkin, R.; Landau, D.; Segev, Y. Endurance exercise and growth hormone improve bone formation in young and growth-retarded chronic kidney disease rats. Nephrol. Dial. Transplant. 2016, 31, 1270-1279. [CrossRef] [PubMed]

70. Lee, I.J.; Hilliard, B.; Swami, A.; Madara, J.C.; Rao, S.; Patel, T.; Gaughan, J.P.; Lee, J.; Gadegbeku, C.A.; Choi, E.T.; et al. Growth arrest-specific gene 6 (Gas6) levels are elevated in patients with chronic renal failure. Nephrol. Dial. Transplant. 2012, 27, 4166-4172. [CrossRef]

71. Zhang, C.; Tang, K.; Zhang, Y.; Ma, Y.; Zhuang, R.; Zheng, X.; Jin, B.; Zhang, Y. Elevated Plasma Growth Arrest-Specific 6 Protein Levels Are Associated with the Severity of Disease During Hantaan Virus Infection in Humans. Viral Immunol. 2017, 30, 330-335. [CrossRef] [PubMed]

72. Li, W.; Wang, J.; Ge, L.; Shan, J.; Zhang, C.; Liu, J. Growth arrest-specific protein 6 (Gas6) as a noninvasive biomarker for early detection of diabetic nephropathy. Clin. Exp. Hypertens. 2017, 39, 382-387. [CrossRef]

73. Rankin, E.B.; Fuh, K.C.; Castellini, L.; Viswanathan, K.; Finger, E.C.; Diep, A.N.; LaGory, E.L.; Kariolis, M.S.; Chan, A.; Lindgren, D.; et al. Direct regulation of GAS6/AXL signaling by HIF promotes renal metastasis through SRC and MET. Proc. Natl. Acad. Sci. USA 2014, 111, 13373-13378. [CrossRef] [PubMed]

74. Gustafsson, A.; Boström, A.-K.; Ljungberg, B.; Axelson, H.; Dahlbäck, B. Gas6 and the Receptor Tyrosine Kinase Axl in Clear Cell Renal Cell Carcinoma. PLoS ONE 2009, 4, e7575. [CrossRef] [PubMed]

75. Gustafsson, A.; Martuszewska, D.; Johansson, M.; Ekman, C.; Hafizi, S.; Ljungberg, B.; Dahlbäck, B. Differential expression of Axl and Gas6 in renal cell carcinoma reflecting tumor advancement and survival. Clin. Cancer Res. 2009, 15, 4742-4749. [CrossRef]

76. Gustafsson, A.; Fritz, H.K.M.; Dahlbäck, B. Gas6-Axl signaling in presence of Sunitinib is enhanced, diversified and sustained in renal tumor cells, resulting in tumor-progressive advantages. Exp. Cell Res. 2017, 355, 47-56. [CrossRef]

77. Ciceri, P.; Elli, F.; Braidotti, P.; Falleni, M.; Tosi, D.; Bulfamante, G.; Block, G.A.; Cozzolino, M. Iron citrate reduces high phosphate-induced vascular calcification by inhibiting apoptosis. Atherosclerosis 2016, 254, 93-101. [CrossRef]

78. Park, J.-K.; Theuer, S.; Kirsch, T.; Lindschau, C.; Klinge, U.; Heuser, A.; Plehm, R.; Todiras, M.; Carmeliet, P.; Haller, H.; et al. Growth arrest specific protein 6 participates in DOCA-induced target-organ damage. Hypertension 2009, 54, 359-364. [CrossRef] [PubMed]

79. Shuvy, M.; Abedat, S.; Beeri, R.; Valitsky, M.; Daher, S.; Kott-Gutkowski, M.; Gal-Moscovici, A.; Sosna, J.; Rajamannan, N.M.; Lotan, C. Raloxifene attenuates Gas6 and apoptosis in experimental aortic valve disease in renal failure. Am. J. Physiol. Heart Circ. Physiol. 2011, 300, H1829-H1840. [CrossRef]

80. Qiu, C.; Zheng, H.; Tao, H.; Yu, W.; Jiang, X.; Li, A.; Jin, H.; Lv, A.; Li, H. Vitamin K2 inhibits rat vascular smooth muscle cell calcification by restoring the Gas6/Axl/Akt anti-apoptotic pathway. Mol. Cell. Biochem. 2017, 433, 149-159. [CrossRef] [PubMed]

81. Chen, L.; Chen, W.; Hu, Z.; Bian, J.; Ying, L.; Hong, G.; Qiu, Q.; Zhao, G.; Lu, Z. Protective Effects of Growth Arrest-Specific Protein 6 (Gas6) on Sepsis-Induced Acute Kidney Injury. Inflammation 2016, 39, 575-582. [CrossRef]

82. Giangola, M.D.; Yang, W.-L.; Rajayer, S.R.; Kuncewitch, M.; Molmenti, E.; Nicastro, J.; Coppa, G.F.; Wang, P. Growth arrest-specific protein 6 protects against renal ischemia-reperfusion injury. J. Surg. Res. 2015, 199, 572-579. [CrossRef] 
83. Guo, J.-K.; Marlier, A.; Shi, H.; Shan, A.; Ardito, T.A.; Du, Z.-P.; Kashgarian, M.; Krause, D.S.; Biemesderfer, D.; Cantley, L.G. Increased tubular proliferation as an adaptive response to glomerular albuminuria. J. Am. Soc. Nephrol. 2012, 23, 429-437. [CrossRef]

84. Eng, P.C.; Chua, W.C.-N.; Suk Peng Chew, V.; Wong, P.T.H.; Yin, J.L.; Hambly, B.; McLachlan, C.S. Chronic angiotensin-converting enzyme inhibition up-regulates mouse kidney growth arrest specific-6 protein and the AXL subfamily of receptor tyrosine kinases. J. Renin-Angiotensin-Aldosterone Syst. 2008, 9, 238-241. [PubMed]

85. Batchu, S.N.; Hughson, A.; Gerloff, J.; Fowell, D.J.; Korshunov, V.A. Role of Axl in early kidney inflammation and progression of salt-dependent hypertension. Hypertension 2013, 62, 302-309. [CrossRef]

86. Viegas, C.S.B.; Santos, L.; Macedo, A.L.; Matos, A.A.; Silva, A.P.; Neves, P.L.; Staes, A.; Gevaert, K.; Morais, R.; Vermeer, C.; et al. Chronic Kidney Disease Circulating Calciprotein Particles and Extracellular Vesicles Promote Vascular Calcification: A Role for GRP (Gla-Rich Protein). Arterioscler. Thromb. Vasc. Biol. 2018, 38, 575-587. [CrossRef]

87. Hackeng, T.M.; Rosing, J.; Spronk, H.M.; Vermeer, C. Total chemical synthesis of human matrix Gla protein. Protein Sci. Publ. Protein Soc. 2001, 10, 864-870. [CrossRef] [PubMed]

88. Price, P.A.; Otsuka, A.A.; Poser, J.W.; Kristaponis, J.; Raman, N. Characterization of a gamma-carboxyglutamic acid-containing protein from bone. Proc. Natl. Acad. Sci. USA 1976, 73, 1447-1451. [CrossRef] [PubMed]

89. Schurgers, L.J.; Spronk, H.M.H.; Skepper, J.N.; Hackeng, T.M.; Shanahan, C.M.; Vermeer, C.; Weissberg, P.L.; Proudfoot, D. Post-translational modifications regulate matrix Gla protein function: Importance for inhibition of vascular smooth muscle cell calcification. J. Thromb. Haemost. 2007, 5, 2503-2511. [CrossRef]

90. Furie, B.; Furie, B.C. Molecular basis of vitamin K-dependent gamma-carboxylation. Blood 1990, 75, 1753-1762. [PubMed]

91. Price, P.A.; Rice, J.S.; Williamson, M.K. Conserved phosphorylation of serines in the Ser-X-Glu/Ser(P) sequences of the vitamin K-dependent matrix Gla protein from shark, lamb, rat, cow, and human. Protein Sci. Publ. Protein Soc. 1994, 3, 822-830. [CrossRef]

92. Schurgers, L.J.; Teunissen, K.J.F.; Knapen, M.H.J.; Kwaijtaal, M.; van Diest, R.; Appels, A.; Reutelingsperger, C.P.; Cleutjens, J.P.M.; Vermeer, C. Novel conformation-specific antibodies against matrix gamma-carboxyglutamic acid (Gla) protein: Undercarboxylated matrix Gla protein as marker for vascular calcification. Arterioscler. Thromb. Vasc. Biol. 2005, 25, 1629-1633. [CrossRef]

93. Price, P.A.; Faus, S.A.; Williamson, M.K. Warfarin causes rapid calcification of the elastic lamellae in rat arteries and heart valves. Arterioscler. Thromb. Vasc. Biol. 1998, 18, 1400-1407. [CrossRef] [PubMed]

94. Silaghi, C.N.; Fodor, D.; Gheorghe, S.R.; Crăciun, A.M. Serum total matrix Gla protein: Reference interval in healthy adults and variations in patients with vascular and osteoarticular diseases. Clin. Chim. Acta 2019, 490, 128-134. [CrossRef]

95. Price, P.A.; Thomas, G.R.; Pardini, A.W.; Figueira, W.F.; Caputo, J.M.; Williamson, M.K. Discovery of a high molecular weight complex of calcium, phosphate, fetuin, and matrix gamma-carboxyglutamic acid protein in the serum of etidronate-treated rats. J. Biol. Chem. 2002, 277, 3926-3934. [CrossRef] [PubMed]

96. Roumeliotis, S.; Dounousi, E.; Eleftheriadis, T.; Liakopoulos, V. Association of the Inactive Circulating Matrix Gla Protein with Vitamin K Intake, Calcification, Mortality, and Cardiovascular Disease: A Review. Int. J. Mol. Sci. 2019, 20, 628. [CrossRef]

97. Zoch, M.L.; Clemens, T.L.; Riddle, R.C. New insights into the biology of osteocalcin. Bone 2016, 82, 42-49. [CrossRef]

98. Millar, S.A.; Patel, H.; Anderson, S.I.; England, T.J.; O'Sullivan, S.E. Osteocalcin, Vascular Calcification, and Atherosclerosis: A Systematic Review and Meta-analysis. Front. Endocrinol. 2017, 8, 183. [CrossRef]

99. Plantalech, L.; Guillaumont, M.; Vergnaud, P.; Leclercq, M.; Delmas, P.D. Impairment of gamma carboxylation of circulating osteocalcin (bone gla protein) in elderly women. J. Bone Miner. Res. 1991, 6, 1211-1216. [CrossRef]

100. Kanazawa, I. Osteocalcin as a hormone regulating glucose metabolism. World J. Diabetes 2015, 6, $1345-1354$. [CrossRef]

101. Ducy, P. The role of osteocalcin in the endocrine cross-talk between bone remodelling and energy metabolism. Diabetologia 2011, 54, 1291-1297. [CrossRef] [PubMed] 
102. Cremers, S.; Garnero, P.; Seibel, J.M. Biochemical Markers of Bone Metabolism. In Principles of Bone Biology; Bilezikian, J.P., Raisz, L.G., Martin, T.J., Eds.; Elsevier: San Diego, CA, USA, 2008; Volume 2, pp. 1857-1881.

103. Zhang, M.; Ni, Z.; Zhou, W.; Qian, J. Undercarboxylated osteocalcin as a biomarker of subclinical atherosclerosis in non-dialysis patients with chronic kidney disease. J. Biomed. Sci. 2015, 22, 75. [CrossRef]

104. Csiky, B.; Sági, B.; Peti, A.; Lakatos, O.; Prémusz, V.; Sulyok, E. The Impact of Osteocalcin, Osteoprotegerin and Osteopontin on Arterial Stiffness in Chronic Renal Failure Patients on Hemodialysis. Kidney Blood Press. Res. 2017, 42, 1312-1321. [CrossRef]

105. Lee, N.K.; Sowa, H.; Hinoi, E.; Ferron, M.; Ahn, J.D.; Confavreux, C.; Dacquin, R.; Mee, P.J.; McKee, M.D.; Jung, D.Y.; et al. Endocrine regulation of energy metabolism by the skeleton. Cell 2007, 130, 456-469. [CrossRef] [PubMed]

106. Ducy, P.; Desbois, C.; Boyce, B.; Pinero, G.; Story, B.; Dunstan, C.; Smith, E.; Bonadio, J.; Goldstein, S.; Gundberg, C.; et al. Increased bone formation in osteocalcin-deficient mice. Nature 1996, 382, 448-452. [CrossRef]

107. Hwang, Y.-C.; Jeong, I.-K.; Ahn, K.J.; Chung, H.Y. The uncarboxylated form of osteocalcin is associated with improved glucose tolerance and enhanced beta-cell function in middle-aged male subjects. Diabetes Metab. Res. Rev. 2009, 25, 768-772. [CrossRef] [PubMed]

108. Sarkar, P.D.; Choudhury, A.B. Relationships between serum osteocalcin levels versus blood glucose, insulin resistance and markers of systemic inflammation in central Indian type 2 diabetic patients. Eur. Rev. Med. Pharmacol. Sci. 2013, 17, 1631-1635. [PubMed]

109. Laurance, S.; Lemarié, C.A.; Blostein, M.D. Growth arrest-specific gene 6 (gas6) and vascular hemostasis. Adv. Nutr. 2012, 3, 196-203. [CrossRef]

110. Goruppi, S.; Ruaro, E.; Schneider, C. Gas6, the ligand of Axl tyrosine kinase receptor, has mitogenic and survival activities for serum starved NIH3T3 fibroblasts. Oncogene 1996, 12, 471-480.

111. Kaesler, N.; Immendorf, S.; Ouyang, C.; Herfs, M.; Drummen, N.; Carmeliet, P.; Vermeer, C.; Floege, J.; Krüger, T.; Schlieper, G. Gas6 protein: Its role in cardiovascular calcification. BMC Nephrol. 2016, 17, 52. [CrossRef]

112. Nakano, T.; Higashino, K.; Kikuchi, N.; Kishino, J.; Nomura, K.; Fujita, H.; Ohara, O.; Arita, H. Vascular smooth muscle cell-derived, Gla-containing growth-potentiating factor for $\mathrm{Ca}^{2+}$-mobilizing growth factors. J. Biol. Chem. 1995, 270, 5702-5705. [CrossRef] [PubMed]

113. Hafizi, S.; Dahlbäck, B. Gas6 and protein S. Vitamin K-dependent ligands for the Axl receptor tyrosine kinase subfamily. FEBS J. 2006, 273, 5231-5244. [CrossRef] [PubMed]

114. Wu, G.; Ma, Z.; Hu, W.; Wang, D.; Gong, B.; Fan, C.; Jiang, S.; Li, T.; Gao, J.; Yang, Y. Molecular insights of Gas6/TAM in cancer development and therapy. Cell Death Dis. 2017, 8, e2700. [CrossRef]

115. Ekman, C.; Stenhoff, J.; Dahlbäck, B. Gas6 is complexed to the soluble tyrosine kinase receptor Axl in human blood. J. Thromb. Haemost. 2010, 8, 838-844. [CrossRef] [PubMed]

116. Shea, M.K.; Kritchevsky, S.B.; Hsu, F.-C.; Nevitt, M.; Booth, S.L.; Kwoh, C.K.; McAlindon, T.E.; Vermeer, C.; Drummen, N.; Harris, T.B.; et al. The association between vitamin K status and knee osteoarthritis features in older adults: The Health, Aging and Body Composition Study. Osteoarthr. Cartil. 2015, 23, 370-378. [CrossRef] [PubMed]

117. Viegas, C.S.B.; Simes, D.C.; Laizé, V.; Williamson, M.K.; Price, P.A.; Cancela, M.L. Gla-rich protein (GRP), a new vitamin K-dependent protein identified from sturgeon cartilage and highly conserved in vertebrates. J. Biol. Chem. 2008, 283, 36655-36664. [CrossRef] [PubMed]

118. Cavaco, S.; Viegas, C.S.B.; Rafael, M.S.; Ramos, A.; Magalhães, J.; Blanco, F.J.; Vermeer, C.; Simes, D.C. Gla-rich protein is involved in the cross-talk between calcification and inflammation in osteoarthritis. Cell. Mol. Life Sci. 2016, 73, 1051-1065. [CrossRef] [PubMed]

119. Viegas, C.S.B.; Rafael, M.S.; Enriquez, J.L.; Teixeira, A.; Vitorino, R.; Luís, I.M.; Costa, R.M.; Santos, S.; Cavaco, S.; Neves, J.; et al. Gla-rich protein acts as a calcification inhibitor in the human cardiovascular system. Arterioscler. Thromb. Vasc. Biol. 2015, 35, 399-408. [CrossRef]

120. Tagariello, A.; Luther, J.; Streiter, M.; Didt-Koziel, L.; Wuelling, M.; Surmann-Schmitt, C.; Stock, M.; Adam, N.; Vortkamp, A.; Winterpacht, A. Ucma-A novel secreted factor represents a highly specific marker for distal chondrocytes. Matrix Biol. 2008, 27, 3-11. [CrossRef] [PubMed] 
121. Viegas, C.S.B.; Herfs, M.; Rafael, M.S.; Enriquez, J.L.; Teixeira, A.; Luís, I.M.; van 't Hoofd, C.M.R.; João, A.; Maria, V.L.; Cavaco, S.; et al. Gla-rich protein is a potential new vitamin K target in cancer: Evidences for a direct GRP-mineral interaction. BioMed Res. Int. 2014, 2014, 340216. [CrossRef]

122. Viegas, C.S.B.; Cavaco, S.; Neves, P.L.; Ferreira, A.; João, A.; Williamson, M.K.; Price, P.A.; Cancela, M.L.; Simes, D.C. Gla-rich protein is a novel vitamin K-dependent protein present in serum that accumulates at sites of pathological calcifications. Am. J. Pathol. 2009, 175, 2288-2298. [CrossRef]

123. Sandor, R.; Leucuta, D.; Dronca, E.; Niculae, A.; Cret, V.; Silaghi, C.; Șoimița, S. Low Serum Paraoxonase-1 Lactonase and Arylesterase Activities in Obese Children and Adolescents. Rev. Romana Med. Lab. 2015, 23, 385-395. [CrossRef]

124. Tjwa, M.; Bellido-Martin, L.; Lin, Y.; Lutgens, E.; Plaisance, S.; Bono, F.; Delesque-Touchard, N.; Hervé, C.; Moura, R.; Billiau, A.D.; et al. Gas6 promotes inflammation by enhancing interactions between endothelial cells, platelets, and leukocytes. Blood 2008, 111, 4096-4105. [CrossRef] [PubMed]

125. Weiner, D.E.; Tabatabai, S.; Tighiouart, H.; Elsayed, E.; Bansal, N.; Griffith, J.; Salem, D.N.; Levey, A.S.; Sarnak, M.J. Cardiovascular outcomes and all-cause mortality: Exploring the interaction between CKD and cardiovascular disease. Am. J. Kidney Dis. 2006, 48, 392-401. [CrossRef]

126. Yamada, H.; Kuro-O., M.; Ishikawa, S.-E.; Funazaki, S.; Kusaka, I.; Kakei, M.; Hara, K. Daily variability in serum levels of calciprotein particles and their association with mineral metabolism parameters: A cross-sectional pilot study. Nephrology (Carlton) 2018, 23, 226-230. [CrossRef] [PubMed]

127. GBD 2015 Disease and Injury Incidence and Prevalence Collaborators. Global, regional, and national incidence, prevalence, and years lived with disability for 310 diseases and injuries, 1990-2015: A systematic analysis for the Global Burden of Disease Study 2015. Lancet Lond. Engl. 2016, 388, 1545-1602.

128. Miner, J.H. The glomerular basement membrane. Exp. Cell Res. 2012, 318, 973-978. [CrossRef]

129. Lee, P.; Wu, X. Review: Modifications of human serum albumin and their binding effect. Curr. Pharm. Des. 2015, 21, 1862-1865. [CrossRef] [PubMed]

130. Soichiro, U.; Katsuhiro, G.; Hiroshi, H.; Yoshiyuki, M. Plasma Levels of Growth Arrest Specific Protein (Gas6) and the Soluble Form of Its Tyrosine Kinase Receptor Axl (sAxl) in Patients with Hepatocellular Carcinoma. J. Cancer Ther. 2013, 4, 632-639.

131. Rathore, B.; Singh, M.; Kumar, V.; Misra, A. Osteocalcin: An emerging biomarker for bone turnover. Int. J. Res. Med. Sci. 2016, 4, 3670-3674. [CrossRef] 